\title{
The Facets of Transitional Justice and 'Red Terror' Mass Trials of Derg Officials in Post-1991 Ethiopia: Reassessing its Achievements and Pitfalls
}

Kinkino Kia Legide

Hawassa University, kinkinok@gmail.com

Follow this and additional works at: https://digitalcommons.usf.edu/jacaps

Part of the Criminal Procedure Commons, Human Rights Law Commons, Law and Society Commons, and the Peace and Conflict Studies Commons

\section{Recommended Citation}

Legide, Kinkino Kia (2021) "The Facets of Transitional Justice and 'Red Terror' Mass Trials of Derg Officials in Post-1991 Ethiopia: Reassessing its Achievements and Pitfalls," Journal of African Conflicts and Peace Studies: Vol. 4: Iss. 2, . DOI: https://doi.org/10.5038/2325-484X.4.2.1142

Available at: https://digitalcommons.usf.edu/jacaps/vol4/iss2/6

This Article is brought to you for free and open access by the Open Access Journals at Digital Commons @ University of South Florida. It has been accepted for inclusion in Journal of African Conflicts and Peace Studies by an authorized editor of Digital Commons @ University of South Florida. For more information, please contact digitalcommons@usf.edu. 


\section{The Facets of Transitional Justice and 'Red Terror' Mass Trials of Derg Officials in Post-1991 Ethiopia: Reassessing its Achievements and Pitfalls}

\section{Cover Page Footnote}

Kinkino Kia Legide (LLB; LLM) is a Lecturer at Hawassa University School of Law, and currently, he is a Candidate of Advanced MSc in Governance and Development (Conflict and State Reconstruction Track) at the University of Antwerp, Belgium. The initial draft of this paper is presented at 'Module Papers Seminar' at Institute of Development Policy (IOB), University of Antwep, 3 and 4 June 2019. He can be reachedviakinkinok@gmail.com. 
Legide: The Facets of Transitional Justice and Red Terror Trials in post-1991 Ethiopia

\section{Introduction}

The world has witnessed a tantalizing mass violence committed by state and non-state actors over the years. As Williams and Buckley-Zistel noted, "the $20^{\text {th }}$ century has often been labeled the century of genocides and mass violence [and...] questions regarding the perpetration of violence continue to be pertinent". ${ }^{1}$ At the end of the state-perpetrated violence, two important perplexing questions need to be addressed: the first one is how to ensure post-violence accountability or punish impunity, and the second one concerns how to transform a society wrecked by war and prolonged conflicts into a durable peace in a non-violent means. ${ }^{2}$ One such effort to deal with these questions is through the implementation of a transitional justice measures whose vitality increased since $1990 \mathrm{~s}^{3}$ Generally, transitional justice encompasses a broader theme than criminal prosecutions though criminal justice processes (trials, tribunals, or vetting of perpetrators) are the most prominent in the transitional justice discourse. ${ }^{4}$

According to David Crocker, the conceptual notion of transitional justice should rest on eight goals: truth, public platform for victims, accountability and punishment, the rule of law, compensation to victims, institutional reform, long-term development, reconciliation and public deliberation. ${ }^{5}$ The point is that individual measures are inadequate so that employing them in a holistic approach helps better theorize and understand transitional justice measures. Drawing its foundational inspiration from the Nuremberg trials, the contemporary understanding of TJ has been expanded after the overthrow of dictatorships in Latin America, the end of cold war politics, the largescale conflicts in the Balkan region, and widespread violence in Africa and Asia. ${ }^{6}$

Ethiopia has had a brief experience of implementing transitional justice measures of one sort or other, specifically the one related to Derg's 'Red Terror' trials. In 1974, the popular revolution in Ethiopia brought a half-century rule of Emperor Hailesellassie I and feudal aristocracy of ancien regime to its end. Due to the absence of organized political party, the military committee called Derg, came to control power. Though war and violence perpetrated by state or regional warlords are not uncommon in Ethiopia, the statesanctioned perpetration of violence reached its highest point during the years of 1975-78. This was the time when a military junta called Derg, after overthrowing the last emperor of ancien regime in 1974, unleashed

\footnotetext{
${ }^{1}$ Buckley-Zistel, S., Beck. T. K., Braun, C. \& Mieth, F. (2014). Transitional Justice Theories: An Introduction. In S. Buckley-Zistel, T. Koloma Beck, C. Braun \& F. Mieth (eds.), Transitional Justice Theories (pp. 1-16). Oxon and New York: Routledge, p. 1.

${ }^{2}$ Jarstad, A.K., \& Sisk, T.D., (eds.). (2008). From War To Democracy: Dilemmas of Peacebuilding. Cambridge: Cambridge University Press.

${ }^{3}$ Joanna R. Quinn, (2017), The Development of Transitional Justice, In Lawther, Cheryl, Moffet, L. \& Jacobs, D., (eds.), Research Handbook on Transitional Justice, Cheltenham: Edward Elgar Publishing, pp. 11-33.

${ }^{4}$ Anja Mihr, (2017), Regime Consolidation through Transitional Justice in Europe: The Case of Germany, Spain, Turkey, International Journal of Transitional Justice Vol. 11, Issue 1, pp. 113-131.

5 . David Crocker (1999) as cited in Buckley-Zistel, S., Beck. T. K., Braun, C. \& Mieth, F. (2014). Transitional Justice Theories: An Introduction. In S. Buckley-Zistel, T. Koloma Beck, C. Braun \& F. Mieth (eds.), Transitional Justice Theories (pp. 1-16). Oxon and New York: Routledge, p. 5.

${ }^{6}$ Levis Oneg (2012). Introduction, In Moses Chrispus Okello el al (eds), Where the Law Meets Reality: Forging African Transitional Justice, Cape Town: Pambazuka Press, p.1.
} 
what came to be infamously known as mass killing campaign of 'red terror' against students, intelligentsia and other social forces whom it labelled 'anti-revolutionary' and 'reactionary forces'.?

It unleashed a revolutionary killing campaign infamously known as 'Red Terror' against civilian organizations who opposed its ascendancy to power. This heinously devoured thousands of students, intellectual and opposition forces who were labelled as 'enemies of revolution', 'anti-revolutionary,' and reactionary forces'. ${ }^{8}$ This augurs with tantalizing mass violence committed in the name of the state which the world has witnessed that resulted in far more deaths and destruction of property than compared to 'conventional offenders'. ${ }^{9}$ The most serious state crimes are genocides, crimes against humanity, terror, politicide, inhumane and degrading treatment and other kinds of politically motivated mass violence. The major aim of the state-perpetrated violence is "to take systematic actions against particular groups for their destruction or subjugation". ${ }^{10}$

Following the collapse of Derg by the struggle of ethno-regional forces, the victorious coalition called Ethiopian Peoples' Revolutionary Democratic Front (hereinafter called EPRDF) established a Transitional Government (TGE) in 1991 and attempted to take a certain form of transitional justice measures in the postCold War context. In 1992, TGE established a Special Prosecutor's Office (hereinafter called SPO) as a responsible organ to deal with Derg's Red Terror atrocities. Its key mandate was to investigate and bring perpetrators to criminal trials, and also ancillary role to produce historical records for posterity. The trial was the first attempt of its kind in African continent to deal with genocide and crimes against humanity solely by domestic tribunal. Moreover, the Red Terror trial "constitute the most extensive judgement of human rights violations since the Nuremberg trials at the end of the Second World War". ${ }^{11}$ The government also decided to undertake the trial by its own in domestic courts. The lengthy trial culminated nearly after two decades in 2007 when the former leader col. Mengistu Hailemariam was found guilty of genocide and sentenced to death in abstentia. However, Ethiopia only barely figures in international transitional or postconflict justice literatures and scholarly work on it is scanty.

While the EPRDF's response to the Derg's atrocities partly succeeds in avoiding impunity, the response measures were not without challenges. As this paper strongly argues, one of the limitations was that the response adopted the narrower model of transitional justice measures. The trial process was also criticized as imposition of the victor's interpretation of justice, whose legitimacy was also compromised by the climate of continued human rights violations by current regime itself. Therefore, given the current political turmoil, a question as to what the achievements and limitations of Ethiopia's response were, and whether the country has utilized the Red Terror trials as a critical learning opportunity to realize societal transformation should be re-examined. So, by making a review of literature, laws and government reports,

\footnotetext{
${ }^{7}$ Trovoll, K., Schaefer, C. \& Girmachew Alemu Aneme (2009). The 'Red Terror' Trials: The Context of Transitional Justice in Ethiopia. In K. Trovoll, C. Schaefer, \& Girmachew Alemu Aneme (eds). The Ethiopian Red Terror Trials: Transitional Justice Challenged. (pp.1-16). Suffolk: James Currey.

${ }^{8}$ Tronvoll, Schaefer \& Girmachew, (2009), ibid; Jennifer Balint, (2012), Genocide, State Crime and the Law: In the Name of the State. Oxon: Routledge.

${ }_{9}^{9}$ Rohne, H. C., Arsovska, J., \& Aertsen, I. (2008). Challenging Restorative Justice-State-based Conflict, Mass Victimsation and the Changing Nature of Warfare. In I. Aertsen, J. Arsovska, H.C. Rohne, M. Valinas \& K. Vanspauwen (eds.). Restoring Justice After Large-Scale Violent Conflicts: Kosovo, DR Congo and the IsraeliPalestinian Case (pp. 3-45). Devon: William Publishing.

${ }^{10}$ Balint, J. (2012). Genocide, State Crime and the Law: In the Name of the State. Oxon: Routledge, p. 14.

${ }^{11}$ Independent. (1 April 1996). Masters of Ethiopia's Red Terror Face Trial for Genocide. Retrieved $\quad$ from :https://www.independent.co.uk/news/world/masters-of-ethiopias-red-terror-facetrial-for-genocide-1302752.html
} 
this paper attempts to make balanced assessment of the achievements and limitations of the Red Terror trials in relation to then available alternatives and current mainstream transitional justice frameworks.

The paper has seven sections. Following this introduction, section two discusses the coming to power of Derg and puts the Red Terror crimes in context. Section three provides a brief overview of the concept of transitional justice in post-conflict context. Section four examines the measures taken by Ethiopia against transitional justice frameworks. The fifth section briefly looks at the achievements and challenges of the Red Terror trials, and the last section concludes.

\section{The 1974 Revolution and the Coming to Power of the Derg 2.1. The Revolution}

The mainstream historiography of Ethiopia holds that it existed as a polity for about three thousand years. However, Ethiopia with its present geographical territory and ethno-linguistic component emerged only in the $19^{\text {th }}$ century. King Menelik of Shoa (later emperor) launched successive conquests to adjoining territories incorporating formerly autonomous peoples of the south, southeast and southwest. ${ }^{12}$ After his death in 1916, the traditional autocracy took its modern shape when Ras Tefer Mekonnen, a regent to the throne since 1916, claimed lineage from 'Tribe of Judah', and self-sanctified 'Elect of God', came to be crowned as Emperor Hailesellassie I of Ethiopia in $1931 .{ }^{13}$ Seen as a reformer, he introduced the country's first ever modern written constitution and established bi-cameral parliament. ${ }^{14}$ The period after a brief Italian occupation of Ethiopia (1936-41) saw a gradually precipitation of the opposition to the regime, which was inflicted by extreme centralization, with archaic exploitative feudal economic system. This system turned the bulk of southern peoples of the country to landless tenants and serfdom later resulting in peasant rebellions. However, the most significant and radical challenge leading to the downfall of the decaying monarchical order came from a notable Ethiopian Students Movement who were battling the ancien regime since mid-1960s. ${ }^{15}$

According to a historian Bahru Zewde, ${ }^{16}$ the year 1965 is conventionally taken as a "landmark in the history of the Ethiopian Student Movement ... [and] era of revolutionary commitment" when the University students chanted "Land to the Tiller" in their demonstration in Addis Ababa. In the absence of political organizations and in defiance of old political order, the students' movement assumed the "burden of opposition with heroism and dignity". ${ }^{17}$ After spontaneous strikes by the teachers, students, taxi drivers, the army also mutinied in parallel, the first one of which took place in 'Sidamo', south Ethiopia in Jan. 1974. This was followed by mutiny of the army fighting in Eritrea. ${ }^{18}$ Gradually, their demands grew more than material benefits such as salary increase. Despite its earlier moderate orientations, a clandestine and

\footnotetext{
${ }^{12}$ Bahru Zewde, (1991), The History of Modern Ethiopia ( $1^{\text {st }}$ ed). London: James Currey; Merera, (2003), Competing Ethnic Nationalism and the Quest for Democracy, 1960-2000, Maastricht: Shaker Publishing.

${ }^{13}$ Bahiru Zewde, (1991), ibid.

14 James C.N Paul \& Christopher Clapham, (1967), Ethiopian Constitutional Development: A Source Book, Vol. 2. HIS University Press.

${ }^{15}$ Balsvik, R. (1985). Haile Sellassie's Students: The Intellectual and Social Background to Ethiopian Revolution, 1952-1977. East Lansing: Michigan State University Press.; Bahru, (1991).

${ }^{16}$ Bahru Zewde (2014), The Quest for Socialist Utopia: The Ethiopian Student Movement c. 1960-74. London: James Currey. p. 101.

${ }^{17}$ Bahru Zewde (2014), ibid, p. 226.

18 John Markakis, (2011), Ethiopia: The Last Two Frontiers. Suffolk and New York: James Currey.
} 
more radical wing was formed by the low-ranking military officers who "shared a radical left-wing revolutionary orientation". ${ }^{19}$ Amidst growing opposition and decaying monarchical order, the old regime crumbled. On 12 September 1974, the monarchy who reigned for half a century was deposed by the military officers and was reported dead within a year 'under suspicious circumstances' ${ }^{20}$ Summarized in a single sentence, the cause of the revolution "came from the incapacity of a post-feudal socio-political system to modernize itself when faced with the challenges of the transformation of the second half of the twentieth century". ${ }^{21}$

The regime change that took place in Ethiopia in 1974 marks a real revolution and was the "... the only major social revolution yet to have occurred in Africa". ${ }^{22}$ A long-time Ethiopianist political scientist Clapham thus writes: "A revolution marks a fundamental and irreversible change in the organization of a society; [...] Such a change has taken place in Ethiopia: a change indeed in many ways comparable to those experienced during the 'classic' revolutions of France and Russia". 23

\subsection{The Coming to Power of Derg and Prelude to 'Red Terror'}

The popular revolution which was rallied by intelligentsia, teachers, taxi drivers and other members of society came to a direct confrontation with the military. For years, the Ethiopian army remained a separate, privileged social class and was strong and better army next only to South African due to American help. ${ }^{24}$ The Derg's come to power should not be of much surprise. While a radical student opposition to the old regime heightened, 'clear and viable alternatives' have not been formulated. According to Claudio Moffa:

"Inspite of the clear political character of their demands, neither the students nor the working class nor other sections of the urban population (not to speak of the peasants) had managed to give birth to a coherent organization that could operate nationally...In this situation, the power vacuum that had happened could not be filled by any other social groups except the army, the only organized force existing in the country. And it was with this army that all "parties" would henceforth have to deal with". ${ }^{25}$

In the absence of clear alternatives and strong political organization due to what Markakis calls "lack of imagination" 26 , military as the only organized body came to seize such opportunity. After establishing a Provisional Military Administrative Council (PMAC), the Derg started to launch series of brutal campaign of state mass murder of what later came to be known as 'red terror'. In the words of a prominent observer,

${ }^{19}$ Gerard Prunier, (2015), The Ethiopian Revolution and the Derg Regime. In G. Prunier \& E. Ficquet (eds.). Understanding Contemporary Ethiopia: Monarch, Revolution and the Legacy of Meles Zenawi, London: Hurst, (pp. 209-232), p. 216.

${ }^{20}$ Weibel, (2017), The Ethiopian Red Terror. In T. Spear (ed.), Oxford Research Encyclopedia: African History, (pp.NA). Oxford: Oxford University Press; Kjetil Tronvoll, 2013), Ethiopia, In Encyclopedia of Transitional Justice,

Vol. 2, (pp.167-173), Cambridge: Cambridge University Press.

${ }^{21}$ Pruneir, (2015), p. 211.

22 Clapham, C., (2004). The Challenge of Democratization in Ethiopia, Whitehall Papers, 62:1, 71-82, p. 76)

23 Clapham, C. (1988). Transformation and Continuity in a Revolutionary Ethiopia, Cambridge: Cambridge University Press, p. 1.

${ }^{24}$ Gerard Prunier, (2015), The Ethiopian Revolution, ibid.

${ }^{25}$ As quoted in Prunier, 2015, p. 217)

${ }^{26}$ Markakis (2011), p. 180. 
Legide: The Facets of Transitional Justice and Red Terror Trials in post-1991 Ethiopia

"the authors of revolution who were youthful urban intelligentsia" were "fated to be devoured by the revolution they unleashed", ${ }^{27}$ and the red terror targeted that end as we shall see below.

\subsection{The Unleashing of the 'Red Terror'}

"The Ethiopian Red Terror is the most significant and least studied atrocity of late twentieth century Africa". 28

Bereft of ideological guidance, Derg hijacked the 'Land to the Tiller', the revolutionary slogan of students, and afterwards, Marxism and Ethiopian nationalism were employed. While radical Marxism (later Ethiopia's scientific socialism) provided ideological guidance, Ethiopian nationalism, manifested by 'a commitment to nation-state project was the revolution's driving force'. ${ }^{29}$

Thereafter, the Derg mobilized the students to countryside for Zemecha, literacy campaign to educate the peasantry on the Marxist credentials. The Zemecha was seen as a tactic to remove radical challengers and civilian rivals from the urban centers in its bid to control power absolutely. Then, the civilian component of the revolution came to the direct confrontation and determined to fight even for their life. ${ }^{30}$ The MEISON (Amharic abbreviation for All Ethiopian Socialist Movement) and EPRP (Ethiopian Peoples' Revolutionary Party), the two civilian organizations emerging from the students' movement, emerged to challenge the Derg's dictatorship and called to establish civilian government. ${ }^{31}$

While MEISON followed a gradualist approach and initially agreed to collaborate with the Derg hoping to tame and educate it, the radical EPRP, whose hostility grew against the military, refused to collaborate for the mobilization of the masses. Afterwards launched the operation of random killing, well grounded in the major cities against the military officers and its civilian allies. The Derg dubbed it "anarchist, "enemy of the revolution", as "white terror" and responded with what it named 'red terror against white terror' named along the Russian counterpart of 1917 revolution period. ${ }^{32}$ Frictions and enmity between EPRP and MEISON also precipitated ground for further suicidal red terror. Red terror was exemplified by adopting 'extrajudicial revolutionary violence' as the official practice of the regime." The years from 1976 to 1978 marked the heyday of the Red Terror in which "public killings became a normalized aspect of Ethiopia's revolutionary situation". 33

No one accurately tells when the Red Terror started. Bahru Zewde argues that the situation of initial armed confrontation started from within the army on the early days when they deposed the emperor on 12

${ }^{27}$ John Markakis (2011, p. 161), ibid.

28 Alex de Waal, (2019), [blurb comment to] Conley, B. (2019). Memory from the Margins: Ethiopia's Red Terror Martyrs Museum, Palgrave MacMillan.

${ }^{29}$ Markakis, (2011), p. 161.

${ }^{30}$ Pruneir, (2015), ibid.

${ }^{31}$ Clapham, (1988), ibid.

32 (Trovoll, 2013).

33 (Weibel, 2017) 
September 1974. ${ }^{34}$ Friction between initial chair General Aman Andom and Major Mengistu "precipitated not only the death of the General, but also the summary execution of over 50 government officials and dignitaries as well as dissidents from within the military. The execution of 'the sixty' [members of imperial government] initiated a culture of massive killing with impunity". ${ }^{35}$ This gradually laid the ground for the would-be state killings and also breed the seeds of 'Red Terror'. "[T] he penalty for being on the wrong side was almost always death". ${ }^{36}$ After rounds of purging its members, Mengistu Hailemariam emerged as the sole undisputed dictator. ${ }^{37}$

In a remarkable coincidence, one of the atrocious regimes, a Pol Pot's Khmer Rouge regime in Cambodia, conducts the similar atrocity and from 1975 to 1978 , roughly one and half to two million people perished. ${ }^{38}$ In the words of one historian, "From late 1976 to the end of 1978, Ethiopia was to live through two particularly atrocious years". ${ }^{39}$ Series of terror were unleashed, and a historian captures the third phase of it as follows:

"The carnage of May Day 1977 was the dress rehearsal for the massive killing that characterized the third phase of government terror. If the [earlier] phase [s] of terror was measured and centrally directed, the third was one where every 'revolutionary' became a law into himself. This was the period of 'netsa ermejja' (which could be translated in broad terms as unrestricted license to kill). Terror had become democratized! The Addis Ababa city council at the top and the kebeles at the bottom were entrusted with their indispensable revolutionary defense squads at the bottom were entrusted with full authority to kill any suspect...". 40

People as victims were terrorized and summarily executed by the revolutionary bodies, sometimes at dark "and their bodies left in the open to serve as a deterrent to all those who were harboring similar thoughts of counter-revolution". ${ }^{41}$ The most extreme of brutality of the Derg, the bodies of the massacred were left in the streets 'to be ravaged by hyenas at night. Some families who were fortunate enough to identify the bodies of their murdered youths were required to pay for the bullets that were used to kill their sons and daughters before they could take the corpse for a proper funeral". ${ }^{42}$ Executioner shoots twice since it was profitable as victim's relatives paid for each bullet. ${ }^{43}$

The Derg's notorious killing campaign of red terror was "the most systematic and infamous campaign of human rights violations perpetrated by the Derg... [which] killed a generation of mostly young intellectuals

\footnotetext{
34 Bahru Zewde (2009), The History of Red Terror: Contexts \& Consequences. In K. Trovoll, C. Schaefer and Girmachew Alemu Aneme (eds.). The Ethiopian Red Terror Trials: Transitional Justice Challenged (pp. 17-32). Suffolk: James Currey.

${ }^{35}$ Bahru, (2009), ibid, p. 23.

${ }^{36}$ Clapham, (1988), p. 52.

${ }^{37}$ Clapham, (1988), ibid.

${ }^{38}$ Cheryl S. White (2017), Bridging Divides in Transitional Justice: The Extraordinary Chambers in the Courts of Cambodia, Antwerp, Cambridge: Intersentia.

${ }^{39}$ Gerard Prunier, (2015), ibid, p. 220.

${ }^{40}$ Bahru, (2009), p. 28.

41 Bahru, (2009), p. 29.

${ }^{42}$ Kjetil Tronvoll et al, (2009), p. 3.

${ }^{43}$ Luc Huyse, (2009), All Thingd Pass, Except the Past. New Goff, Mariakerke: AWEPA, p. 76.
} 
without a resort to the rule of law". ${ }^{44}$ The number of people killed during the red terror campaign remains indefinite. According to Weibel (2019), the scope of red terror crime is not limited to a random killings and extra-judicial executions. Evidences show that more than 50,000 deaths might have took place in regional wars with insurgents, much more were subjected to tortures and other forms of vigorous state violence. As one study puts it, the estimated people killed 'ranges from 150,000 to 500,000 '. ${ }^{45}$ In a recent entry to Oxford Encyclopedia, one observer puts:

“...on such casualty figures one must add the tens of thousands who were subjected to torture and often lengthy extrajudicial detention, and the hundreds of thousand whose lives were profoundly affected by the mental health crisis, the loss of loved ones and their social and economic support, and the widespread exile that attended the Red Terror for so many. ${ }^{46}$

In the words of Human Rights Watch/Africa Watch (1991), the red terror campaign, has been characterized as "one of the most systematic uses of mass murder by the state witnessed in Africa". ${ }^{47}$ Paradoxically, however, the human atrocity of Derg red terror is one of the significant events of untold history and how that violent past has been dealt with has not been rigorously analyzed.

\section{Dealing with Past Wrongs: An Overview of Transitional Justice Measures}

The world has witnessed a turbulent mass violence committed by state and non-state actors over the years. As Williams and Buckley-Zistel noted, "the $20^{\text {th }}$ century has often been labeled the century of genocides and mass violence [and...] questions regarding the perpetration of violence continue to be pertinent". ${ }^{48}$ The legacies of past atrocities during the violent conflict involves the commission of serious crimes such as mass murder, forced disappearances, war crimes, mass rape, ethnic cleansing, acts of genocide, and crimes of other form against humanity. ${ }^{49}$ These horrors took place in such places as the Holocaust, Armenia, Cambodia, Rwanda, Sierra Leone, Ethiopia and many other African, Latin American and Balkan countries. ${ }^{50}$ Transitional justice as a field of enquiry and also political practice is concerned with the questions of how to deal with the massive human rights violations, ensure accountability and be transformed in to the establishment of a decent civil order in the wake of gross violation of human rights. ${ }^{51}$ It is often pursued 'following periods of political turmoil, state repression, or armed conflict.' ${ }^{52}$ As Olsen, Paine \&

\footnotetext{
44 Tronvoll et al, (2009), p. 4)

45 Tronvoll et al, 2009 p. 4.

${ }^{46}$ Weibel, (2017), ibid, no p.no)

${ }^{47}$ As cited in Firew K. Tiba, (2013)

48 Timothy Williams and Buckley-Zistel (2018), Perpetrators and Perpetrators of Mass Violence: Actions, Motivations and Dynamics ( $1^{\text {st }}$ ed.), p. 1.

${ }^{49}$ Newman, (2002 as cited in Nevin T. Aiken, (2013), Identity, Reconciliation and Transitional Justice: Overcoming Intracticability in Divided Societies, Oxon: Routledge.p. 1).

${ }^{50}$ William A. Schabas, (2002), The Abolition of Death Penality in International Law (3 ${ }^{\text {rd }}$ ed.), Cambridge: Cambridge University Press; Jennifer Balint, (2016), Genocide, State Crime, ibid.

51 See Eisikovits, Nir (2014 [2017], Transitional Justice, In The Stanford Encyclopedia of Philosophy (Fall 2017 Edition), Edward N. Zalta (ed.), URL = <https://plato.stanford.edu/archives/fall2017/entries/justice-transitional/>.); See also Claudio Corradetti, Nir Eisikovits, Jack V. Rotondi, (eds.) (2015), Theorizing Transitional Justice, Surrey: Ashgate; Nevin T. Aiken, (2013), Identity, Reconciliation, ibid.

52 Tricia D. Olsen, Leigh A. Paine \& Andrews G. Reiter (2010), Transitional Justice in Balance: Comparing Processes, Weighing Efficacy, Washington, D, C: United States Institute of Peace, p. 1.
} 
Reiter (2010) observed, these mechanisms of transitional justice fall in to 'three broad, overlapping categories:

"mechanisms of accountability for past crimes, including trials, truth commissions, and lustration policies; victim-oriented restorative justice mechanisms, including reparations, construction of monuments, and public memory projects; and mechanisms of security and peace, including amnesties and pardons, constitutional amendments, and institutional reforms.". ${ }^{53}$

It often concerns what Michael Newman ${ }^{54}$ says contending views, an idea which explains the struggle to face inherent difficulties faced after past atrocities "and the legacy of such violations will continue far beyond the establishment of new regime or government.

Transitional justice is the field in a constant growth and expansion, ${ }^{55}$ and its meanings and subjects also expanded considerably over the years. This constant growth also broadened its scope and activities, 'making it complex and contested term for academics and practitioners". ${ }^{66}$ As Cheryl Lawther and Luke Moffett recently noted, even today, there is a considerable debate about what the transitional justice is and its main goals and dynamics. ${ }^{57}$ Ruti Teitel, who for the first time coined the term, defines transitional justice as "the conception of justice associated with periods of political change, characterized by legal responses to confront the wrongdoings of repressive predecessor regimes." 58

Generally, however, the concept of transitional justice has expanded and summarizes the concerns of how the new regimes deals with the human rights abuses committed by their predecessor regimes or actors. Though the general concerns of the transitional justice have been the above one, various definitions have been provided by different authors and organizations. According to the UN Secretary General Kofi Annan, transitional justice is formalized with in the UN system. A widely cited 'Report of the Secretary-General defines Transitional Justice as:

[...] the full range of processes and mechanisms associated with a society's attempts to come to terms with a legacy of large-scale past abuses, in order to ensure accountability, serve justice and achieve reconciliation. These may include both judicial and non-judicial mechanisms, with differing levels of international involvement (or none at all) and individual prosecutions, reparations, truth-seeking, institutional reform, vetting and dismissals, or a combination thereof. ${ }^{59}$

\footnotetext{
${ }^{53}$ Olsen, Paine \& Reiter (2010), Transitional Justice in Balance, ibid. P. 1.

${ }^{54}$ Michael Newman (2019), Transitional Justice: Contending with the Past, Cambridge: Polity Press.

${ }^{55}$ Catherine Turner (2017), Transitional Justice and Critique, In Cheryl Lawther, Luke Moffet and Dov Jacobs (eds), A Research Handbook of Transitional Justice, Edward Elgar, pp. 52-73.

${ }^{56}$ Louis F. Monroy-Santander, 2018). Bosnia and Herzegovina: The Challenges and Complexities of Transitional Justice, In Fabio Andres Diaz Pabon (ed.), Truth, Justice and Reconciliation in Colombia: Transitioning from Violence, Routledge

57. Cheryl Lawther and Luke Moffett, 2017, Introduction-Researching Transitional Justice: The Highs, the lows and the expansion of the Field, In Cheryl Lawther, Luke Moffet and Dov Jacobs (eds), A Research Handbook of Transitional Justice, Cheltenham: Edward Elgar, p. 3.

${ }^{58}$ Ruti Teitel, "Transitional Justice Genealogy” (2003) 16 Harvard Human Rights Journal, p. 16; see also Ruti Teitel, Transitional Justice, Oxford: Oxford University Press 2000), p. 3.

${ }^{59}$ UN (2004), Report of the Secretary-General on the Rule of Law and Transitional Justice in Conflict and PostConflict Societies'.
} 
Attempts at bringing perpetrators to justice in post-conflict settings is not new a phenomenon in history of transitions. According to Claudio Corradetti, Nir Eiskovits and Volpe Rotondi, the philosophical debate over transitional justice can be traced back to ancient Greece. According to them, the Athenians were said to have addressed some of the key questions of transitional justice in the "triology of The Oreteia "where Athena played the transitional role of casting the decisive vote for pardoning Orestes and saving him from the Furies (the Erinnyes)." 60

Originally, transitional justice emerged as a narrow sphere of inquiry, with a focus on traditional concerns of prosecutions, truth telling, restitution and institutional reform. This was because, in its original understanding, transitional justice measures were meant to deal with a transition from authoritarianism to liberal democracy, and this informed the kinds measures to be taken. ${ }^{61}$ These were drawn on the consequentialist lines in the sense that they were meant to smooth the transition. The transitional justice measures, especially in the context of immediate post-cold War context such as criminal prosecution, truth telling, lustration and reparation were implemented cautiously because they were feared to imperil peaceful transitions. ${ }^{62}$ As McAuliffe argues, though the international community of human rights for long has shown that it is desirable to ensure accountability or acknowledgement as the ends themselves. ${ }^{63}$

According to Naomi Roht-Ariazza, ${ }^{64}$ the history of war crime trials can be traced back as far as to 14 th century. The aftermath of both world wars was also followed by trials despite their success or pitfalls. Crimes such as tortures and its perpetrators were brought to trials in Greek in 1970s; post-Franco Spain saw reparation efforts and the same story appears in post-Salazar Portugal. ${ }^{65}$ In the post-Cold War period, some measures were taken in transition from dictatorship in Latin America and Philippines and marked by negotiated settlement of transition in post-Apartheid South Africa. ${ }^{66}$

The conception of idea of transitional justice and its emergence as a 'self-standing field of inquiry' is related to the post-Cold War 'third-wave of democratization' as it took place specially in Latin America as the concept is employed as a 'means of facilitating the evolution of those states involved, from bloody dictatorships to liberal democracies'. ${ }^{67}$ Throughout, the transitional justice responses to mass atrocities has been considered as an 'integral element of liberal peacebuilding. Literature treats transitional justice as 'central to contemporary peacebuilding efforts'. ${ }^{68}$ As such, it is considered as an application of liberal

${ }^{60}$ Corradetti, Eiskovits and Rotondi (eds.) (2015). Theorizing Transitional Justice, ibid, p. 1.

${ }^{61}$ Padraig McAuliffe, (2017), Transformative Transitional Justice and the Malleability of Post-conflict States, Cheltenham: Edward Elgar, p. 36.

${ }^{62}$ Padraig McAuliffe, (2017), Transformative Transitional Justice, ibid.

${ }^{63}$ Padraig McAuliffe, (2017), Transformative Transitional Justice, ibid.

${ }^{64}$. Naomi Roht-Arriaza (2006), The New Landscape of Transitional Justice, In Naomi Roht-Arriaza and Javier Mariezcurrena (eds.), Transitional Justice in the Twenty-First Century: Beyond Truth Versus Justice, Cambridge: Cambridge University Press.

${ }^{65}$ Naomi Roht-Arriaza (2006), The New Landscape of Transitional Justice. Ibid.

66. Naomi Roht-Arriaza (2006), The New Landscape of Transitional Justice, ibid, p. 2.

${ }^{67}$ Kora Andrieu (2014). Political Liberalism after Mass Violence; John Rawls and a 'Theory' of Transitional Justice, In Zustel et al., Transitional Justice Theories, (pp. 85-104), ibid, p. 89.

${ }^{68}$. Chandra Lekha Sriram (2009). Justice as Peace? Liberal Peacebuilding and Strategies of Transitional Justice. In Roger Mac Ginty and Oliver Richmond (eds.), The Liberal Peace and the Post-War Reconstruction: Myth or Reality? Oxon: Routledge. p. 89. 
justice concept to political change, and "includes not only juridical answers to past repressions, but also restorative, administrative and economic measures". ${ }^{69}$ As Kieran McEvoy notes, however, this new field of inquiry has been signified by a trend of 'the dominance of legalism'. ${ }^{70}$ According to him, transitional justice is annexed to international criminal justice by lawyers and 'it has 'become over dominated by narrow, legalistic lens which impedes both scholarship and praxis' ${ }^{71}$ As such, the original focus of transitional justice emerged as a narrow sphere of inquiry, with a focus on traditional concerns of prosecutions, truth telling, restitution and institutional reform. This was because, in its original understanding, transitional justice measures were meant to deal with a transition from authoritarianism to liberal democracy, and this informed the kinds measures to be taken. ${ }^{72}$ These were drawn on the consequentialist lines in the sense that they were meant to smooth the transition.

Judicial accountability for serious violations of human rights were sought after the immediate World War II period chiefly marked by Nuremberg and Tokyo Trials carried out on Axis powers, and attempts were made to prosecute them in domestic courts. ${ }^{73}$

According to Willima Schabas ${ }^{74}$, the Nuremberg Trials contributed to the evolution of the transitional justice field. It held that to initiate a war of aggression is an international crime, and atrocities committed by a government against its own people are punishable as an international crime-these was drawn from then emerging human rights movement. Nuremberg also contains the suggestion that international responsibility is imposed upon states to ensure that perpetrators of international crimes are brought to justice". 75 "Since 1989, the use of international judicial institutions to hold accountable those who are accused of perpetrating atrocities has burgeoned". ${ }^{76}$ This saw the establishment of ad hoc international tribunals and the also the negotiation of Rome Statute of ICC in 1998 which entered in to force in 2002. ${ }^{77}$

Expounding its vital precedent setting role, professor Schabas says: "Centuries from now, the Nuremberg trial will be seen as one...defining moment" in human history, "if it is not already". ${ }^{78}$ Though criminal trials seemed to be the most important instrument to be employed during transitional justice in earlier days, the legal redress available for mass atrocity has been inadequate particularly after the 1970s. With democratization process ongoing in Eastern Europe, Latin America and others, new dimensions such as truth commissions, lustrations and others took the center to reckon with the brutal past. The role for criminal

\footnotetext{
${ }^{69}$ Kora Andrieu (2014). Political Liberalism after Mass Violence, ibid, p. 89.

${ }^{70}$ Kieran McEvoy (2008), Letting Go of Legalism: Developing a 'Thicker' Version of Transitional Justice, In McEvoy and McGregor (eds.), Transitional Justice from Below: Grassroots Activism and the Struggle for Change, London: Hart Publishing, p. 16.

${ }^{71}$ Kieran McEvoy (2008), Letting Go of Legalism, ibid, p. 16.

${ }^{72}$ Padraig McAuliffe, (2017), Transformative Transitional Justice, p. 36).

73. Ajata Fijalkowski and Raluca Grosescu, 2015, Introduction in Ajata Fijalkowski and Raluca Grosescu (eds.), Transitional Criminal Justice in Post-Dictatorial and Post-Conflict Societies, Cambridge, Antwerp, Portland: Intersentia, p. 2.

${ }^{74}$ William A. Schabas, (2002), Unimaginable Atrocities: Justice, Politics and Rights at the War Crimes Tribunal, Oxford: Oxford University Press, p. 1.

75 William A. Schabas, (2002), The Abolition of Death Penality in International Law, ibid.

${ }^{76}$ William A. Schabas, (2002), The Abolition of Death Penality, ibid, (p. 2)

77 William A. Schabas, (2002), The Abolition of Death Penality, ibid, (p. 2).

${ }^{78}$ William A. Schabas, (2002), The Abolition of Death Penality, ibid, (p. 1).
} 
trials, though important in transitional justice, was criticized as narrow ${ }^{79}$, however, only to be reinstated to its leading position of primacy during Yugoslavia conflict and trial in the 1990s.

Drawing its foundational inspiration from the Nuremberg trials, the contemporary understanding of transitional justice has been expanded after the overthrow of dictatorships in Latin America, the end of Cold War politics, the largescale conflicts in the Balkan region, and widespread violence in Africa and Asia. ${ }^{80}$ The transitional justice measures, especially in the context of immediate post-Cold War context such as criminal prosecution, truth telling, lustration and reparation were implemented cautiously because they were feared not to imperil peaceful transitions. ${ }^{81}$ As McAuliffe argues, though the international community of human rights for long has shown that it is desirable to ensure accountability or acknowledgement as the ends themselves ${ }^{82}$.

The international tribunals are criticized for their retroactive nature, and this happens according to Schabas, due to the 'inevitable consequence of their political dimension', and their incomplete structures. ${ }^{83}$

Transitional Justice has also its face in Africa. However, is complex and multifaceted ${ }^{84}$, and in the words of Jessica Johnson and George H. Karekwaivanane, exhibits 'divergent understandings and experiences of justice from across the continent ${ }^{\prime}{ }^{85}$, more broadly. The establishment of Truth and Reconciliation Commission in post-Apartheid South Africa in 1995 and International Criminal Tribunal for Rwanda (ICTR) in 1990s and ICC's continued focus on Africa also made the African continent a center of 'looming' academic works and debates in transitional justice. ${ }^{86}$ Jasmina Brankovic and Hugo van der Merwe (2019) further note that other factors such as democratization efforts following Cold War, South Africa's TRC influence and 'prominence of international bodies' operating in the continent through their interventions has made Africa a prominent subject in the study of transitional justice. According to Anders and Zenker, what distinguishes African measures on transitional justice from the Latin American counterpart is that the latter implemented it against the abuse of rights by the authoritarian regimes while the former implemented it in response to widespread violence and civil wars. ${ }^{87}$ "Rather than rejecting transitional justice as yet another externally imposed agenda, African institutions are articulating their own values and norms that draw on African human rights frameworks and reflections on national experiences within the continent". ${ }^{88}$ This latter position is reflected in the recent adoption of AU Transitional Justice Policy in August 2018. ${ }^{89}$

\footnotetext{
${ }^{79}$ Fijalkowski and Raluca Grosescu, (2015), Introduction, ibid, p. 2.

${ }^{80}$ Levis Oneg (2012). Introduction in Moses Chrispus Okello el al (eds), Where the Law Meets Reality: Forging African Transitional Justice, Cape Town: Pambazuka Press, p. 1.

${ }^{81}$ McAuliffe, 2017), Transformative Transitional Justice, ibid.

${ }^{82}$ McAuliffe, 2017), Transformative Transitional Justice.

83 Paul Seils (2017), The Place of Reconciliation in Transitional Justice: Conceptions and Misconceptions, International Center for Transitional Justice (ICTJ) Briefing, p. 4.

${ }^{84}$ Jasmina Brankovic and Hugo van der Merwe, (eds.) (2019), Advocating Transitional Justice: The Role of Civil Society, Springer, p. xi.

${ }^{85}$. Jessica Johnson and George H. Karekwaivanane, (2018) (eds.), Pursuing Justice in Africa: Competing Imaginaries and Contested Practices, Athens: Ohio University Press, p. 2.

${ }^{86}$ Gerhard Anders \& Olaf Zenker, (2015), Transition and Justice: An Introduction, In Gerhard Anders \& Olaf Zenker (eds.), Traditions and Justice: Negotiating the Terms of New Beginnings in Africa (1st ed),)1-19) John Willey, p. 1.

${ }^{87}$ Gerhard Anders \& Olaf Zenker, (2015), Transition and Justice, ibid.

${ }^{88}$ Jasmina and Van der Merwe, (2019), Advocatiing Transitional Justice, ibid, xi.

${ }^{89}$ African Commission on Human and Peoples' Rights (2019), Study on Transitional Justice and Human and Peoples' Right in Africa, ACHPR, Banjul.
} 
As we noted above, during the first generation of the transitional justice measures, much emphasis has been given to the criminal prosecution of the perpetrators along with efforts to establish truth commissions. ${ }^{90}$ Further studies in the field of transitional justice revealed, however, that single approach to reckoning with the past has proved inadequate so that a wide range of measures should be considered within the transitional justice field. ${ }^{91}$ Focus should go beyond holding perpetrators accountable, and it should also involve truth telling and victims reparations.

Transitional justice has 'ambitious' goals which aims at transformation of societies or their regeneration in a post-war socio-economic life. ${ }^{92}$ As Kora observes, it involves taking a wide range of measures, including political, economic, cultural, sociological and psychological measures. ${ }^{93}$ Among diverse claims about the outcomes of transitional justice, justice, truth, reparation, and reconciliation are generally seen as the most widely cited measures. ${ }^{94}$ As Naomi Roht Ariazza convincingly puts it, "[O]nly by interweaving, sequencing and accommodating multiple pathways to justice could some kind of larger justice in fact emerge". 95

\section{The Post-1991 Ethiopia's Approach to Dealing with the Derg-era Crimes}

\subsection{Which Type of Transitional Justice Measure for Ethiopia?}

Kim and Hong demonstrated that a post-conflict state's decision to select a transitional justice measure over another is determined mainly by the outcomes of the newly ended wars. ${ }^{96}$ According to them, criminal trials are most likely to take place where there is 'decisive, one-sided victory' whereas truth commissions and reparations are results of negotiated settlements. Non-negotiated transitions took place after Armenian genocide, Rwanda genocide, Cambodia after Khmer Rouge, former Yugoslavia, and Ethiopia. ${ }^{97}$ Negotiated transitions happened in post-Apartheid South Africa and former military regimes in Latin America. ${ }^{98}$ As Kieran McEvoy notes, during the post-conflict trials, "law becomes an important practical and symbolic break with the past, an effort to publicly demonstrate a new-found accountability and legitimacy". ${ }^{9}$

After the Marxist dictatorship of Derg was toppled in 1991, the new victorious rebels led by Tigrayan Peoples' Liberation Front (TPLF) established a coalition called EPRDF and controlled the political power. ${ }^{100}$ It soon organized a July 1991 Peace Conference, drafted a Transitional Charter, and established

\footnotetext{
${ }^{90}$. Roht-Arriaza and Mariezcurrena (eds.), (2006), Transitional Justice in the Twenty-First Century, ibid.

${ }^{91}$ Roht-Arriaza, et al, ibid.

${ }^{92}$ Kora Andrieu, (2014), p. 89.

93 Kora Andrieu, (2014), p. 89.

94 Elin Skaar, (2013), Transitional Justice Methods, Processes and Practices, In Nadya Nedelsky and Lavinia Stan (eds.), Encyclopedia of Transitional Justice, New York: Cambridge University Press, Vol. 1, p. 64.

95 Roht-Arriaza, (2006), p. 8.

${ }^{96}$ Kim, NK \& Hong, MH, (2016). Politics of Pursuing Justice in the Aftermath of Civil Conflict. Faculty Publications: Political Science. Paper 77.

${ }^{97}$ Balint, J. (2012). Genocide, State Crime and the Law, ibid, pp. 189-196.

${ }^{98}$ Balint, J. (2012). Genocide, State Crime and the Law, ibid.

${ }^{99}$ Kieran McEvoy (2007), Beyond Legalism: Towards a Thicker Understanding of Transitional Justice, Journal of Law and Society, Vol. 34, Issue 4, pp. 411-440, p. 417.

100 Trovoll, K., Schaefer, C. \& Girmachew Alemu Aneme (2009). The 'Red Terror' Trials: The Context of Transitional Justice in Ethiopia, ibid, (pp. 1-16).
} 
Transitional Government of Ethiopia (hereinafter TGE). ${ }^{101}$ The next key agenda was how to deal with the Derg-era crimes.

Ethiopia chiefly adopted post-conflict trial from among alternative measures. According to then leader, Meles, the government's decision was prosecution, ${ }^{102}$ it did not intend to establish truth and reconciliation commission, and amnesty was ruled out since it "would send a wrong signal for the people and future politicians". ${ }^{103}$ Moreover, no international nor hybrid tribunals were opted. ${ }^{104}$ Massive lustration measuresa legal mechanism to disqualify and restrict civil and political rights of former officials-were implemented with proclamation No. 3/1991 which under Art. 8 provided “..[N]o Working Party of Ethiopia (WPE) or security members may participate in any political activity". ${ }^{105}$ This restriction later also extended to judges by other law, which resulted in purging of numerous judges at all levels (ibid). ${ }^{106}$

\subsection{The Establishment of SPO and Mass Trials of 'Red Terror' Crimes}

In 1992, the TGE established SPO as a responsible organ which the state employs to deal with political crimes of the past regime. From its establishing proc. No 22/1992, its core function is:

"[T]o conduct investigations and institute proceedings in respect of any person having committed or responsible for the commission of an offence by abusing his position in the party, the government or mass organization under the Derg-WPE regime.". ${ }^{107}$

In addition, its ancillary duty is also provided in the preamble:

"In the interest of a just historical obligation to record for posterity the brutal offences committed [...] against the people of Ethiopia and to educate the people and make them aware of those offences in order to prevent the recurrence of such a system of government". ${ }^{108}$

At the beginning of the process, the SPO reiterated that amnesty is rejected to discharge Ethiopia's international obligation to bring perpetrators to trial. ${ }^{109}$ The chief prosecutor of SPO, Girma Wakijira, was

\footnotetext{
${ }^{101}$ Vaughan, S, (1994), The Addis Ababa Transitional Conference of July 1991: Its Origins, History and Significance, Centre of African Studies, The University of Edinburgh.

102 Ryle, J. (1996). The Trial of the Derg in Ethiopia: A Reporter's Story, Einstein Forum, Potsdam, Retrieved from: https://johnryle.com/?article=the-trial-of-the-derg-in-ethiopia

103 As cited in Kjetil Trovoll (2013), Ethiopia, In Encyclopedia of Transitional Justice, Vol. 2, (pp.167173), Cambridge: Cambridge University Press. p. 169.

${ }^{104}$ Maogoto, J. N. (2013). Reading the Shadows of History: The Turkish and Ethiopian 'Internationalized' Domestic Crime Trials. In K. Heller and G. Simpson (eds.), The Hidden Histories of War Crimes Trials (pp. 289-305). Oxford: Oxford University Press.

105 Quoted in (quoted in Kjetil et al, 2009, The 'Red Terror' Trials, pp. 8-9.

106 See Proclamation No. 23/92, Proclamation No. 23/92, A Proclamation to Provide for the Independence of the Judicial Administration. Transitional Government of Ethiopia: Addis Ababa.

107. See (Art. 6, of Special Public Prosecutor's Office Establishment Proclamation, Proclamation No. $22 / 1991$. Transitional Government of Ethiopia: Addis Ababa.

108 (Preamble, $5^{\text {th }}$ para, Proclamation No. 22/1991.

109 Human Rights Watch (1994). Ethiopia: Reckoning Under the Law, Vol. 6, No. 11. (Retrieved from: https://www.hrw.org/sites/default/files/reports/ethiopia94d.pdf).
} 
the former EPRP member and survivor of Red Terror whom critics equated to "appointing a holocaust survivor as a prosecutor for the Nuremberg Tribunal" "110. Following its establishment, the SPO focused on prosecutions and undertook a lengthy, challenging and risky job of investigations against the former officials and disbanded army. ${ }^{111}$ The special prosecutors of SPO "were engaged in controversial, demanding and often distressing or dangerous work..."112. In a 17 pages Report submitted to the UN Office at Geneva in January 1994, the SPO explained about its activities, progresses, challenges and called on states to extradite fugitives voluntarily, 'as a matter of comity'. ${ }^{113}$

\section{Analysis of Ethiopia's Response for Past Wrongs in Light of the Transitional Justice Frameworks}

In this section I shall focus only on four broader frameworks such as Truth, Accountability, Reconciliation, and Reparation (TARR). It is to be acknowledged that some of these TARR framework measures commonly employed today were not common as such back in early 1992 and judging Ethiopia's measures by current standards may be contested. But, for want of standardized framework of analysis, I will employ them to briefly examine whether the measures conformed to TARR frameworks and achieved the broader goals of transitional justice.

\subsection{The Criminal Accountability: Mass Prosecution of Derg Officials}

The concept that individuals who commit the international crimes such as genocide, crime against humanity and war crimes are responsible for their perpetration has been considered as the lasting legacy of the international tribunals such as Nuremberg and Tokyo trials established after the WWII. ${ }^{114}$ According to its proponents, in transitional justice processes, trials and prosecutions are sought to be the most meaningful and legitimate measure to deal with the past atrocities. It seriously takes the view that past wrongs can be effectively dealt with by demonstrating that no one is above the law and thereby attempting to ensure the rule of law. It is part of the ceremony to reckon with the past and to create a certain historical narrative engrained in trials, cross-examinations, admissions, and court judgements. It has been argued that criminal prosecutions are one of the important avenues to give 'recognition to the victims as right holders, and it also has a role of establishing the trustworthy of the legal and judicial system particularly in a situation where the rule of law and fair trial. ${ }^{115}$ Accordingly, the legitimacy of the new order can be maintained only

\footnotetext{
${ }^{110}$ Frew Tiba (2011). The Trial of Mengistu and Other Derg Members for Genocide, Torture and Summary Executions in Ethiopia. In C. Murungu \& J. Biegon (eds.), Prosecuting International Crimes in Africa (pp. 163-183). Pretoria: Pretorial University Law Press, p. 167.

${ }^{111}$ Vaughan, S. (2009). The Role of the Special Prosecutor's Office. In K. Tronvoll, C. Schaefer \& Girmachew Alemu Aneme (eds). The Ethiopian Red Terror Trials, ibid.

112 Vaughan, S. (2009), The Role of the Special Prosecutor's Office, ibid, p. 55.

${ }^{113}$ Office of the Special Prosecutor. (28 Jan. 1994). Ethiopia: Report of the Office of the Special Prosecutor, Letter from the Permanent Representative of the Transitional Government of Ethiopia to the United Nations Office at Geneva, Addressed to the Assistant Secretary-General for Human Rights. Geneva: UN, 1994. Retrieved from: https://www.usip.org/publications/1993/01/special-prosecutors-office-ethiopia; US Institute of Peace, (1 Dec. 1994), United States Bureau of Citizenship and Immigration Services (1 December 1994). Ethiopia: Update on Political Conditions, [Retrieved from: https://www.refworld.org/docid/3ae6a609c.html [accessed 24 May 2019]

114 Brianne McGonigle Leyh, (2016), National and Hybrid Tribunals: Benefits and Challenges, in Peter Malcontent (ed), Facing the Past: Amending Historical Injustices through Instruments of Transitional Justice, Intersentia, pp, 115

${ }^{115}$ Gallen, J. (2017). The International Criminal Court: In the Interests of Transitional Justice? In C. Cheryl, L. Moffet \& D. Jacobs (eds.), Research Handbook on Transitional Justice (pp. 305-327).
} 
by disallowing impunity on the basis of the strict adherence to criminal law provisions. While collective punishment of the vanquished en masse would precipitate discontent and sow the breeds the seeds of resentment, individualization of responsibility through judicial courts "would secure in the person punished the conviction of guilt. ${ }^{116}$

According to Huyse, bringing perpetrators of heinous state crimes to justice serves two principal roles: firstly, it "advances the cause of building or reconstructing a morally just order. The second reason has to do with the consolidation of the regime that succeeds the authoritarian order or of a just-won peace". ${ }^{117}$ So, in transitional justice processes, trials are seen as part of the ceremony to reckon with the past and to create a certain "historical narratives engrained in trials", and court judgements. ${ }^{118}$ By putting law at the center, it also has a role of establishing the trustworthy of the legal and judicial systems. ${ }^{119}$

On the other hand, punishment in the context of transition, in societies coming out of extended violence may prove difficult. For instance, as Murphy notes, those who committed serious human rights violations may 'still wield influence and threaten transition if prosecuted". ${ }^{120}$ This refers to a long-debated "peacejustice dilemma'. Evidences of violence may be lost or destroyed which might make the prosecution process unsuccessful. ${ }^{121}$ This challenges in prosecution has led many post-conflict (transitional societies) to adopt other measures which may be termed as alternative mechanisms to reckon with past wrongs. ${ }^{122}$ The other alternatives for instance would include truth commissions, reparations, lustrations. This alternative means employed remained debatable as far as the theory of retributive justice is concerned, which emphasizes that the perpetrators of massive human rights violations need to be punished to serve justice and correct them (ibid). Generally, Cheryl S. White notes that 'The rationale informing the choice of trials as post-conflict justice mechanisms ... was that of accountability and deterrence of perpetrators' ${ }^{123}$ Some states also sought to establish historical records through court trials. However, the effort in creating historical narratives through court judgement has been contested on the basis that is inadequate to establish fuller and broader images.

In Ethiopia, after a difficult and lengthy investigation, the SPO managed to file 360 cases on October 1994 against top Derg officials who were suspected of committing Red Terror crimes. ${ }^{124}$ While much of the cases were brought before then Central High Court, other regional supreme courts also tried several cases. ${ }^{125}$ Regarding the initial classification of charges:

116 (Bass, 2002 cited in Nir Eisikovits, 2017)

${ }^{117}$ Luc Hyse (2013). Transitional Justice After War and Dictatorship: Learning From European Experiences (19452010), Centre for Historical Research and Documentation on War and Contemporary Society CEGES-SOMA, p. 9. Retreived from: http://www.cegesoma.be/docs/media/Recherche/TransJustFinalReport.pdf

${ }^{118}$ Brianne M. Leyh, (2016), National and Hybrid Tribunals, ibid, p. 115.

${ }^{119}$ Gallen, J. (2017). The International Criminal Court, ibid.

${ }_{120}$ Colleen Murphy (2015), Transitional Justice, Retributive Justice and Accountability for Wrongdoing, In Claudio et al Theorizing Transitional Justice, Ashgate Publishing.

${ }^{121}$ Colleen Murphy (2015), Transitional Justice. Ibid.

${ }^{122}$ Colleen Murphy (2015), Transitional Justice, ibid.

${ }^{123}$ Cheryl S. White (2017), Bridging Divides in Transitional Justice, ibid, p. 9.

${ }^{124}$ K. Tronvoll, (2013), Ethiopia, In Encyclopedia of Transitional Justice, Vol. 2; Marshet Ayele. (2018). Prosecution of Politicide in Ethiopia: The Red Terror Trials. The Hague: Asser Press.

${ }^{125}$ Maogoto, J. N. (2013). Reading the Shadows of History, ibid; Vaughan, (2009), Vaughan, S. (2009). The Role of the Special Prosecutor's Office, ibid. 
“... the SPO charged three groups of alleged perpetrators in the Red Terror trials. The first group consists of defendants who were policymakers and senior government and military officials of the Derg government and 146 in number. The two other groups of defendants were military and civilian field commanders that carried out orders as well as passed down orders, 2,433 in numbers, and [third], the individuals who actually carried out many of the orders, 2,619 in number."

Generally, between 1992 and SPO's final report in 2010, about 384 criminal investigation files were opened throughout the country. The charges brought by the SPO mentions that 12,315 individuals were killed during Red Terror. ${ }^{127}$ The charges brought against the defendants included genocide, ${ }^{128}$ crimes against humanity, torture, murder, unlawful detention, rape, forced disappearances, abuse of power and war crimes, among others. ${ }^{129}$

A total of 5,198 people were prosecuted and 5,119 underwent full trial. ${ }^{130}$ About 2,258 individuals were tried in regional supreme courts. From the total individuals charged, 2,188 were tried in absentia, and "remaining 2,931 appeared before the courts". ${ }^{131}$ All Derg officials who appeared pleaded not guilty on varying lines of arguments. ${ }^{132}$ According to HRW's report in 1997, until 1997, 28 detainees died in custody due to poor medical support ${ }^{133}$, and the prison conditions were reported as "very unsatisfactory". ${ }^{134}$ About 8,000 witnesses of prosecution testified, and " 15,214 pieces of documentary evidence were tendered during the trials.". ${ }^{135}$

The case SPO vs. colonel Mengistu Hailemariam et al, the first to be instituted and is the famous case against the top leaders of the Derg. ${ }^{136}$ This file which runs more than 8000 pages, ${ }^{137}$ lumped together 106

${ }^{126}$ Girmachew Alemu Aneme (2009b). The Anatomy of Specials Prosecutor vs. Colonel Mengistu Hailemariam et. al (1994-2008). The International Journal of Ethiopian Studies (4)1 \&2), 1-53, p. 4.

${ }^{127} \mathrm{~K}$. Tronvoll et. al, (2009), The 'Red Terror' Trials, ibid.

${ }^{128}$. It is to be noted that Genocide under Art. 281 of 1957 Ethiopian Penal Code uses the language which clsely parallels words of the Art. 2 of the 1948 UN Convention on Genocide. But it is broadly defined in the Code in a way that it also includes acts to destroy political groups. See http://preventgenocide.org/law/domestic/ethiopia.htm. "In an interlocutory decision in 1995, the court in the Mengistu case held that this expansion was not inconsistent with international law, ${ }^{10}$ as it was of the view that the Genocide Convention only provided for a minimum standard, which could be expanded in domestic law". See Rikhof J, (2018), Rikhof, J. (2018). Case Comment: Dutch Court Convicts Ethiopian War Criminal to Life Imprisonment, PKI Global Just J. 3.Retrived from: http://www.kirschinstitute.ca/casecomment-dutch-court- convicts-ethiopian-war-criminal-life-imprisonment/ ; See also K. Tronvoll et. al, (2009), The 'Red Terror' Trials, ibid, p. 16 \& 32.

${ }^{129}$ Girmachew Alemu Aneme, (2006), Apology and Trials: The Case of the Red Terror Trials in Ethiopia. Journal of African Human Rights Law (6), 64-84; Maogoto, (2013), Reading the Shadows of History, ibid.

${ }^{130}$ Marshet Ayele. (2018). Prosecution of Politicide in Ethiopia, ibid, p. 172; Frew Tiba (2011), The Trial of Mengistu and Other Derg Members for Genocide, ibid, p. 163.

${ }^{131}$ Marshet Ayele. (2018). Prosecution of Politicide in Ethiopia, ibid, 174.

${ }^{132}$ Ryle, J. (1996). The Trial of the Derg in Ethiopia, ibid.

133 Human Rights Watch. (1 Dec.1997). Ethiopia- The Curtailment of Rights, Retrieved from: https://www.refworld.org/docid/3ae6a8554.html [accessed 21 May 2019].

${ }^{134}$ Amnesty International. (16 Feb. 1993). Amnesty International's Concerns Regarding the Continued Detention in Ethiopia of Officials of the Former Government. Toronto: Amnesty International.

135 (SPO Report, 2010 cited in Marshet, ibid, p. 172)

136 (Girmachew, 2017)?

137 The Economist (2007). Ethiopia: An Archive of Murder Past. Retrieved from, https://www.economist.com/middleeast-and-africa/2007/09/27/an-archive-of-murders- past 
defendants, and among them, 105 were found guilty (except top official, corporal Begashaw who is acquitted), and 52 of them were sentenced to death. ${ }^{138}$ Specifically, Mengistu was convicted of genocide on December 12, 2006 by a Federal High Court and sentenced to life in prison but later the sentence was increased on appeal on May 26, 2008 to a death sentence. A total of 52 death sentences, 182 life in prison sentences, and 921 sentences of rigorous imprisonment from 15 to 25 years were imposed. ${ }^{139}$ The trial process of Derg officials was so protracted which undermined its relevance but the fact that they were convicted garnered support among the families of victims. ${ }^{140}$

To conclude, from a closer reading of the process, we should note two important points. Firstly, Red Terror is not the only crimes committed during Derg days. It is rather, "one of the many faces of human rights abuses committed for seventeen years (1974-91) of the Derg's rule". ${ }^{141}$ Moreover, crimes committed by other groups who even triggered initial hostility were never prosecuted or condemned, which is criticized as unjust and partial. Secondly, one should also note that the situation of the Red Terror trials "were not scenarios in which all the accused were convicted across the board". ${ }^{142}$ For those who were sentenced to death, the sentence remained unenforced as it should be certified by the Republic's President, and he/she is authorized to commute death penalty to life imprisonment which he did. ${ }^{143}$ In 2011 , "those who had served two-thirds of their sentences were released on parole". ${ }^{144}$ Moreover, one of the serious limitations of the prosecution process is that except a few instances, those tried in abstentia never served their sentences. Most notably, the master mind of Red Terror, Mengistu enjoys sanctuary in Zimbabwe until today.

\subsection{Establishing Truth}

Seeking to deal with the past wrongs also increasingly has been approached through the intermediary of truth commissions as an alternative to criminal trials. The use of Truth commissions as an alternative or complementary to criminal prosecutions has begun from the experience of Chile. ${ }^{145}$ The 1995 South African TRC draws a lesson from a Chilean experience (ibid). Truth commissions were defined by Hayner as: Those bodies that share the following characteristics:

... (1) truth commission focus on the past; (2) they investigate a pattern of abuse over a period of time, rather than a specific event; (3) a truth commission is a temporary body, typically in operation for six months to two years, and completing its work with the submission of a report; and (4) these

\footnotetext{
${ }^{138}$ Marshet, 2018), Prosecution of Politicide in Ethiopia, ibid

139 Tadesse Simie Metekia, (2019), Punishing Core Crimes in Ethiopia: Analysis of the Domestic Practice in Light of and in Comparison with Sentencing Practices at the UNICTS and the ICC, International Criminal Law Review 19, pp. 160-190. p. 162.

140 Reuters, (Jan. 20, 2007), Ethiopia's Mengistu found Guilty of Genocide. Retrieved from: https://www.reuters.com/article/us-ethiopia-mengistu-genocide/ethiopias-mengistu-found-guilty-of-genocideidUSL1286585920061212

${ }^{141}$ Firew K. Tiba, (2013), (2013), Mass Trials and Modes of Criminal Responsibility for International Crimes: The Case of Ethiopia. In K. Heller \& G. Simpson (eds.). The Hidden Histories of War Crimes Trials (pp. 306-324). Oxford: Oxford University Press, p. 308.

142 (Marshet Ayele, (2018), p. 209.

143 See Art. 28 (2), 1995 Ethiopian Constitution.

144 (Marshet Ayele, (2018), ibid, p. 174.

145 Williams and Nagy, (2012)
} 
commissions are officially sanctioned, authorized, or empowered by the state (and sometimes also by the armed opposition, as in a peace accord". ${ }^{146}$

According to Colleen Murphy, truth commissions "do not focus primarily on individual perpetrators and victims in isolation, but rather on patterns of interaction and structures of institutions that permit, sanction, or promote such patterns". ${ }^{147}$ Like amnesty, truth commissions document the actions, but does not take retributive measure such as criminal punishment imposed by the state. As Luc Huyse summarizes, “...Truth commissions should unearth and reveal the whole truth-or as much as possible to find. They should ensure that suspected perpetrators are prosecuted". ${ }^{148}$

One of the desirable qualities of truth commissions is that they are less confrontational and at the same time they do not ignore the violations and make efforts to do something for the victims. ${ }^{149}$ In the transitional justice literature, truth commissions help to neutralize and mediate the competing contradictions between 'forces of denial and acknowledgement'. ${ }^{150}$ Truth commissions are remembered for their contribution to mark the move away from the prosecution model on the principle of individualized criminal responsibility to a wider "effective and necessary component of peacebuilding". ${ }^{151}$

In the transitional justice literature, truth inquiry bodies or commissions are remembered for their contribution to mark the move away from the prosecution model on the principle of individualized criminal responsibility to a wider "effective and necessary component of peacebuilding". ${ }^{152}$ They are also viewed as ones which help to neutralize and mediate the competing contradictions between 'forces of denial and acknowledgement'. ${ }^{153}$

The most notable truth commission was the South African Truth and Reconciliation Commission established with the Act 34 of $1995 .{ }^{154}$ It was charged with "establishing as complete a picture as possible of the causes, nature and extent of the gross violations of human rights which ... as well as facilitating the granting of amnesty ... and by recommending reparation measures in respect of them". ${ }^{155}$ According to Nir Eiskovitis, the South African Truth and Reconciliation Commission 'with its amnesty-for-truth arrangement', was the resulting political compromise meant to avoid both punishment and impunity'. ${ }^{156}$ Initially, the ANC demanded for retributive justice was rejected because it was feared that it would derail the "chance for a democratic South Africa". ${ }^{157}$

\footnotetext{
146. Hayner cited in Joanna R. Quinn, 2017, The Development of Transitional Justice in ... p. 21.

${ }^{147}$ Murphy (2017, p. 11)

${ }^{148}$ Luc Huyse (2009), All Thingd Pass,ibid, p. 189.

149 Roht-Arriaza, (2006), ibid, p. 3.

150. Stan Cohem 2001 cited in Cheryl Lawther, (2017), Transitional Justice and Truth Commissions, in Research Handbook of Transitional Justice, p. 342 ff, p. 342.

${ }^{151}$ Cheryl Lawther, (2017), Transitional Justice and Truth Commissions, ibid.

152 (Stan Cohem 2001 cited in Cheryl, 2017, p. 342).

${ }^{153}$ Cheryl, 2017, p. 342).

154 du Bois-Pedain, A. (2007). Transitional Amnesty in South Africa. Cambridge: Cambridge: University Press.

155 du Bois-Pedain, ibid, p. 19, emphasis added.

156 Nir Eiskovitis (2014).

157 (Nir, 2014).
} 
Despite its strong role as an alternative to trials and prosecutions, and also providing a forum for public dialogue ${ }^{158}$ truth commissions have number of challenges. They are criticized in that revealing truth through dialogue may become an 'impediment' to national reconciliation as "it can also promote animosity, reopen wounds and increase political instability”. ${ }^{159}$

Truth Commissions are also criticized on the ground that 'these commissions often lead to the creation of the official, state-sanctioned version of the violent past.' This leads to imposition of a particular version of conflict, defined role for perpetrators and this again makes 'multiplicity of the individual experiences and interpretations of an armed conflict less visible". ${ }^{160}$ Hence, this results in controversies about what is truth and whose version of truth is being presented by the truth during the process of officially sanctioned truthfinding processes. ${ }^{161}$

As Girmachew observed, there were attempts by the 33 top Derg officials on trial who requested then prime minister Meles Zenawi to give them a forum to forward their side of the story where they "beg the Ethiopian public for their pardon for the mistakes done knowingly or unknowingly". ${ }^{162}$ However, "in order to protect the victor's interpretation of events... the government have remained silent about the request". ${ }^{163}$ Asked about the government's approach, Meles said: "We didn't think of a a truth and reconciliation commission". ${ }^{164}$ It is worthy to note that due to SPO's investigation and trials, much evidence has been obtained and better is known about Red Terror crimes. The SPO also produced a 441 pages volume book in Amharic in 2010, which is, however, not like report of truth or enquiry commissions but summary of trials. ${ }^{165}$

The following also captures the pitfalls:

"Ethiopia's choice of prosecution as a transitional justice model means that stories of the sad episode are mainly told through the official channels of court documents and witness testimonies in an adversarial setting. Yet adversarial court proceedings are not necessarily the best mechanisms for getting the true picture of events surrounding the crimes committed". ${ }^{166}$

Marshet also aptly observes that "[....], due to the inherent limitation of judicial processes in establishing the social truth, the comprehensive truth is not unearthed by such means. It is submitted that a truth finding, and historical clarification commission should have been established as complementary to the accountability process". ${ }^{167}$ As one recent study observes, there is also a mismatch between the expectations

158 Sriram, 2011)

${ }^{159}$ Skaar 2013 cited in Fabio Andres Diaz Pabon, 2018, Colombia)

160 (Andrieu, 2010 cited in Fabio Andres Diaz Pabon, 2018)

161 (Loyle \& Davenport, 2016 cited in Fabio Andres Diaz Pabon, 2018).

162 Girmachew Alemu Aneme (2006). Apology and Trials, ibid, p. 67.

163 Tronvoll, 2009), Tronvoll, K. (2009). A Quest for Justice or the Construction of Political Legitimacy?: The Political Anatomy of the Red Terror Trials. In K. Trovoll, C. Schaefer \& Girmachew Alemu Aneme (eds), The Ethiopian Red Terror Trials: Transitional Justice Challenged (pp. 84-97), ibid, p. 96.

${ }^{164}$ Quoted in K. Tronvoll et al, (2009), The Ethiopian Red Terror Trials, ibid, p. 12.

165 Marshet Ayele, (2018).

${ }^{166}$ FirewK. Tiba, (2013), Mass Trials and Modes of Criminal Responsibility for International Crimes, ibid, p. 310.

${ }^{167}$ Marshet Ayele (2018), ibid, p. 263. 
of the criminal trials and the actual outcomes because during trial the witnesses and defendants rationalize their actions and speak 'legalese', not only ordinary explanation of the events. ${ }^{168}$

\subsection{National Reconciliation?}

Reconciliation has long been associated with transitional justice and it is also one of its major goals. ${ }^{169}$ According to Nevin Aiken, there has been an emerging consensus which claims that there exists a causal link relationship between transitional justice, reconciliation and durable peace. ${ }^{170}$ This is because transitional justice measures can serve as a tool to "facilitate societal reconciliation by helping those divided by past violence to put aside their antagonisms and to begin to build a new, more conciliatory relationships with one another". ${ }^{171}$ Opponents of retributive measures argue that solid peace and democratic transformation can only be achieved when we tolerate the past wrongs and focus on national reconciliation. ${ }^{172}$

Fisher underscores that the need for reconciliation is strongly felt in societies that 'have gone through a process of ethnopolitical conflict, as these are marked by a loss of trust, intergenerational transmission of trauma and grievances, negative interdependence'. ${ }^{173}$ The fact that those who have engaged in violent conflict are also bound to live in a closer proximity with each other makes reconciliation a necessary endeavor. Not doing this may lead again to what Fisher terms 'new spiral of violence' and reconciliation serves a necessary role to prevent or reduce 'the desire for revenge'. ${ }^{174}$

Reconciliation is sometimes seen as related to forgiveness which is rooted in the traditions of Judaism and Christianity, and some consider it as a goal whereas others consider it as a process. ${ }^{175}$ Specifically, in local contexts, culture and religion may put great influence on the process of reconciliation. Ruthi Kattumuri and Amalie Kvame Holm (2011) also maintain that forgiveness is important measure which helps compliment the healing of individuals and restoration of societal harmony. Forgiveness can relieve the burdens created by wrongful actions and intolerable debts and suggests that both victim and perpetrator can start afresh (Digeser 2001). It might even imply the reestablishment of moral equality between the parties (Kattumuti and Holm, 2011). ${ }^{176}$

SIDA suggests that it is imperative for the efforts of reconciliation to pay greater attention to the 'connecting tissues' or 'social fabric' that connects together the society. Sida also proposes that human rights-based

168 Bouwknegt, T.B. \& Nistor, A. (2019). Studying 'Perpetrators' Through the Lens of the Criminal Trial. In A. Smeulers, M. Weerdesteijn, \& B. Holá, (eds.), Perpetrators of International Crimes: Theories, Methods and Evidence. (pp. 89-116). Oxford: Oxford University Press.

169 Paul Seils (2017). The Place of Reconciliation in Transitional Justice: Conceptions and Misconceptions, ICTJ Briefing; Skaar, 2012, ibid.

${ }^{170}$ Nevin Aiken (2013), ibid.

171 (Aiken, p. 2)., ibid.

172 Huyse, (2013), ibid.

${ }^{173}$ Fisher (2011), p. 415.

174 Fisher, ibid.

175 Sida (no date).

${ }^{176}$ Ruthi Kattumuri and Amalie Kvame Holm, 2011. Reconciliation and Transitional Justice: The Contribution of Forgiveness Towards Healing and Restoration. In Anheier H., Glasius M., Kaldor M., Park GS., Sengupta C. (eds) Global Civil Society 2011. Global Civil Society Yearbook. Palgrave Macmillan, London. Pp. 38-47. 
approach should be integrated in the reconciliation process, and it should not be imposed on the victims/survivors. In order to reduce collective animosity and communal violence, Aiken suggests that reconsideration of institutional design should be made to engage the fundamental issues of collective identity at the grassroot of collective human rights violations. ${ }^{177}$ A strategy should be sought as part of transitional institutions which contribute to neutralizing or reducing group antagonisms related to group identifications on ethnonational and racial lines which may incite future violence. ${ }^{178} \mathrm{He}$ further suggests that a strong dialogue should be pursued with the works of complex dynamics of conflict transformations in divided societies to move towards more reconciled relations. Paul Seils ${ }^{179}$ urges that since the meaning and aim can vary from place to place, understanding specific context is 'particularly important' for any discussions about reconciliation in transitional justice.

In Ethiopia, the request by the top Derg officials to 'ask forgiveness' from the Ethiopian people met with the silence of government. The defense lawyers for the corpse of Red Terror trials were also reported to have raised that reconciliation should be sought instead of prosecution since the cases are so 'complex and difficult' to be settled in trials. However,

... [In response], the SPO ... went on to aver that not to prosecute flew in the face of the rights of the victims. Apart from this, so the [SPO] affirmed, the Ethiopian government was obligated to prosecute the accused for having allegedly committed the crimes. ${ }^{180}$

This implied that there was a 'rigid' application of retributive model, which is susceptible to result in 'victor's justice'. And at its extreme, "rather than healing and reconciling national wounds, 'victor's justice' may broaden and worsen" the national contradiction. ${ }^{181}$ Ethiopia could have seized such opportunity to achieve a larger national reconciliation and build consensus among its divided society.

\subsection{Reparation for the Victims}

Reparations are also considered as an alternative transitional justice measure to retributive justice/accountability. According to Brandon Hamber, reparations are simply defined as 'things done or given as an attempt to deal with the consequences of political violence'. ${ }^{182}$ Pablo de Greiff holds that the mainstream transitional justice studies has given enormous attention to the measures of criminal trials of human rights violators, but 'much less attention has been paid to ...efforts by way of reparations for the victims' ${ }^{183}$ He contends that from the perspective of the victims of human rights violations, reparations [in the form of material compensation] should be placed at the center of transitional justice measures in postconflict settings or in transitions to democracy. Prosecution may be successful in bringing to trials the perpetrators to justice) though may not be fully successful for several reasons); truth commissions may help

177 Aiken (2013), supra, ibid.

${ }^{178}$ Aiken (2013), ibid, p. 3.

179 Paul Seils (2012), ibid.

${ }^{180}$ As cited in Marshet, (2018), ibid, p. 182.

${ }^{181}$ Tronvoll, (2009), ibid, p. 96.

182 Brandon Hamber (2009), Transforming societies after Political Violence: Truth, Reconciliation, and Mental Health. London and New York: Springer, p. 97.

${ }^{183}$ Pablo de Greiff (2006). Introduction: Repairing the Past: Compensations for the Victims of Human Rights Violations. In Pablo de Greiff (ed.). Handbook of Reparations (pp. 1-20), Oxford: Oxford University Press, p. 1. 
to disclose the fate of those killed or disappeared, and also provide sense of being recognized due to official acknowledgement. Institutional reforms and engineering are more likely a long-term project and only have indirect links to the lives of the victims. Therefore, as de Greiff puts it, "in the absence of other positive and tangible manifestations, truth by itself can easily be considered as an empty gesture, as cheap and inconsequential talk" ${ }^{184}$ So, reparations have at least a direct touch upon the lives of the victims, so that they should be placed at the center of the transitional justice measures. Argentina exemplifies the earliest form of massive reparation programs of any in the Latin American transitions. ${ }^{185}$

In transitional justice field, reparation is often hailed as a measure which represents the "victim-centered transitional justice measures by tailoring measures to victims' needs". ${ }^{186}$ Reparations have at least a symbolic component in that they "acknowledge and recognize the individual's suffering... can help concretize a traumatic event, aid an individual to come to terms with it and help label responsibility". ${ }^{187}$ The Ethiopian prosecution measures did not have any reparation schemes for the victims. Numerous individuals "who were identified by the judgments of the courts as victims of the Mengistu regime's egregious human rights violations have not been given any sort of compensation". ${ }^{188}$ This process failed to put victims at the center and the moral and economic damages caused to the victims remain unaddressed.

\section{Achievements and Challenges of the Red Terror Trials}

\subsection{Achievements}

\subsubsection{Prosecution Symbolized Condemning 'the Culture of Impunity'}

For the first time in its history, and in Africa for that matter, Ethiopia tried to reckon with its past by its own limited domestic capacity. The measures have been seen by commentators as "one of the most ambitious efforts to prosecute former regime perpetrators ever undertaken...". ${ }^{189}$ It was able to ensure, at least, a minimal level of accountability and ensured that perpetrators will not go with impunity. Though protracted and fails to satisfy standards of fair trail, the trial was able to deliver formal, thinner 'justice' which signaled that perpetrators of political violence would learn that impunity has limits. ${ }^{190}$ As HRW legal counsel commented, despite many odds, "we are definitely seeing a trend in which people who commit mass murder are being brought to account". ${ }^{191}$ Moreover, the existence of SPO also helped to reduce the tendency of

\footnotetext{
184 de Greiff ((2006), ibid, p. 2.

185 de Greiff, (2006), ibid.

${ }^{186}$ Moffett, L. (2017). Transitional Justice and Reparations: Remedying the Past?. In L. Cheryl, L. Moffet \& D. Jacobs. (eds.). Research Handbook on Transitional Justice (pp.377-400), Cheltenham: Edward Elgar Publishing, p. 377.

${ }^{187}$ Moffet (2017), ibid, p. 381.

${ }^{188}$ Marshet, 2018, p. 176; See also Firew, 2011, ibid.

189 Conley, B, (April 8, 2019). The Red Terror Martyrs Memorial Museum on Ethiopia's memorial landscape. Retrieved from: https://sites.tufts.edu/reinventingpeace/2019/04/08/the-red- terror- martyrs-memorialmuseum-on-ethiopias-memorial-landscape/.

190 Tronvoll, (2009; 2013), ibid.

191 Quoted in Independent, (13 Dec, 2006). Mengistu found guilty of Ethiopian Genocide, retrieved from https://www.independent.co.uk/news/world/africa/mengistu-found-guilty-of-ethiopian- genocide- 
summary executions and revenge killings, by channeling grievances to be dealt with through legal mechanisms of accountability. ${ }^{192}$

\subsubsection{Establishment of Some truth, public records}

As Vaughan ${ }^{193}$ notes, the early phase of the tasks of SPO was directed at collecting and compiling evidences about the red terror crimes. As remarked above, its enabling law gave ancillary mandate to document historical records, and the SPO achieved a relatively a good deal of success in this regard. It managed to document and preserve the atrocious political crimes and stories of the victims in those evil days. Though not neutral, expanded inquiry report, it also produced a summary of what it achieved in book form in 2010.

\subsubsection{The Establishment of Memorials}

The other legacy of the red terror trials was the erection of Red Terror Martyrs Memorial monument at the heart of Addis Ababa to honor the victims of Red Terror. It carried a catchphrase, 'Never, ever, again!'. A memorial museum has also been established recently in 2010 by independent efforts of Ant-Red Terror committee, a charity established in 1991. However, the Ethiopian memorial attempts lack government ownership and do not get sufficient attention which forced one author recently to say "the history of the Red Terror is sidelined in contemporary politics". ${ }^{194}$

\subsection{Challenges and Limitations}

\subsubsection{Failure to Adopt Broader Notion of Transitional Justice Measures}

A progress in the field of transitional justice revealed that single prosecution method of reckoning with the past has proved inadequate. ${ }^{195}$ As such, its conceptual notion should go beyond prosecutions and should rest on some broader goals such as truth, public platform for victims, compensation to victims, reconciliation and public deliberation. ${ }^{196}$ Even by then standards, Ethiopian trial process failed to take the broader dynamics of transitional justice. Asked about whether the new government considers other alternatives, then country's leader Meles Zenawi responded: “...there was no plausible alternative. They had to come to terms with the events of those years. The only legitimate way was a trial. For the victims and the families of the victims this was the main thing". ${ }^{197}$ As a result, much of the wider measures such as truth finding, reconciliation, and reparation remains largely unaddressed. As one commentator noted, the Red Terror trials in Ethiopia "are only a partial remedy to the massive human rights violations experienced by the country in the past". ${ }^{198}$ The evidence compiled by SPO is not accessible to the wider public, and its

192 Human Rights Watch (1994). Ethiopia: Reckoning Under the Law, Vol. 6, No. 11. Retrieved from: https://www.hrw.org/sites/default/files/reports/ethiopia94d.pdf

${ }^{193}$ Vaughan (2009), ibid.

${ }^{194}$ Conley, (2019), ibid, p. 2.

${ }^{195}$ Roht-Arriaza, (2006), ibid. See also ${ }^{195}$. Natalia Szablewska, Sascha-Dominik Bachmann (2015). Current Issues in Transitional Justice: Towards a More Holistic Approach. Springer.

${ }^{196}$ Buckley-Zistel, Beck, Braun \& Mieth, (2014, ibid, p. 5.

${ }^{197}$ As cited in Ryle, (1996), supra, ibid.

${ }^{198}$ Girmachew Alemu Aneme, (2009a), supra, ibid, p. 117. 
educative and deterrent power goes largely unnoticed. ${ }^{199}$ Failing to adopt a holistic approach, Ethiopia's transitional mechanisms seem to have failed to achieve broader objectives of transitional justice.

\subsubsection{Victor's Interpretation of Justice}

As writers in the post-conflict context point out, the transition period has other flaws. As McAuliffe observes:

"Victory for insurgent forces also results most usually in one form of autocracy being replaced by another...As familiar examples like Ethiopia, Rwanda, and Cote d'Ivoire make apparent, transitional justice is apt to reinforce the power of the stronger party-victors' justice and purges directed at the loser of the conflict tends to trump reconciliation or toleration [...] while, the victor's ability to impose their narrative of conflict obviates the need for truth commissions to consider cause, responsibility or reform...". 200

In this line, the EPRDF's measures against Derg officials are also widely criticized as selective and 'victor's justice against vanquished' ${ }^{201}$ The key point is that the trial completely excludes the crimes committed by other armed groups, including now victorious ones, and makes only Derg officials responsible ${ }^{202}$. According to Tronvoll:

"The fact that the trials only address one segment of the red terror-the violations carried out by the Derg-also fulfills specific purpose since the verdict in this way serve not only as the judgment on the Derg regime but, simultaneously, serve as an implicit acquittal of the TPLF and other ethnic resistance movements against the Derg regime...". 203

Added to this complexity is the 'contradictory interpretation' of the nature of the Ethiopian state. TPLF waged a 17 years guerilla insurgency claiming to 'abolish Amhara domination' and sympathizing ethnic autonomy. ${ }^{204}$ After victory, TPLF wanted to implement its version of Ethiopian state to be a federation composed of various autonomous ethno-linguistic groups. Here, the trials of Red Terror "operate as a political ritual whose function is to legitimate the new system of governance and its rulers. ${ }^{205}$ The critics, largely from previously dominant Amhara elites, delegitimize the response measures as an attack against Ethiopian unity denouncing the new Tigrayan ruling elites as narrow nationalists. ${ }^{206}$

\subsubsection{Mass Adjudication in a Weak, Under-resourced and Non-independent Judiciary and Limits of Domestic Tribunal}

\footnotetext{
${ }^{199}$ Frew Tiba, (2013), ibid.

${ }^{200}$ McAuliffe (2017), Transformational Transitional Justice, ibid, pp. 9-10, emphasis added.

${ }^{201}$ Marhset, 2018; Tronvoll, 2009, ibid.

202 See Tronvoll, 2009; Marshet, 2018; Firew, 2011, supra, ibid.

203 Tronvoll, (2009), ibid, p. 85.

204 Aregawi Berhe, (2008), The Political History of Tigray Peoples Liberation Front: Revolt, Ideology and Mobilization, (PhD Dissertation, University of Amsterdam).

205 " Tronvoll, (2009) ibid, p. 89.

206 (US. Bureau of Immigration and Citizenship Service, 1 Dec. 1994).
} 
As highlighted in the foregoing, the Ethiopian red terror trial is seen as 'ambitious' case in Africa because it was solely conducted by the Ethiopian courts and resources under the penal law of 1957. However, as noted, this decision was not without formidable challenges. For one thing, Ethiopia was then one of the least developed countries on the planet, also plagued by drought and decades of war. Moreover, Ethiopian Red Terror trial process failed to involve important international actors and donors, while other countries in a similar situation involved a 'hybrid tribunals' to withstand different constraints. ${ }^{207}$

The NGOs and other international support organs who initially involved in the process were not willing to continue to operate ${ }^{208}$ Much of the controversy arose as the defendants were detained for longer years without trial, and also increased politicization of the trial, among others. ${ }^{209}$ Albeit these frictions, different governments of Europe and N. America, responded by giving assistance for SPO. ${ }^{210}$ Argentina provided forensic investigators for exhumations of mass graves. ${ }^{211}$

The other constraint relates to the weak judiciary infrastructure. During the Derg, "the courts were subservient to the Mengistu regime" 212 and after, they were demolished and under resourced. Judges and prosecutors were inexperienced to carry out the complex, massive criminal trial of international nature. This was further worsened by the shortage of judges following massive purge of judges from the courts. ${ }^{213}$ It also diminished the capacity of the judiciary and added to the problems of an overloaded system. ${ }^{214}$

The other related problem is bringing huge number of defendants in a single file. Surprisingly, 106 defendants were brought together on single criminal file of SPO vs Mengistu et al, while Nuremberg Tribunal tried only 24 in single file, and maximum of only 7 for former Yugoslavia. As Firew ${ }^{215}$ commented, this "demonstrates how unwieldy the Ethiopian counterpart has been when compared to similar large-scale trials". Lack of adequate provision of legal assistance through defense counsel also proved challenge. ${ }^{216}$ As Human Rights Watch documented, SPO detained many defendants "for almost six years before they were brought to court". ${ }^{217}$ Moreover, the case of Mengistu which was instituted in October 1994, dragged on for nearly 17 years, only finally to be handed down in 2008. Due process of law was not observed, ${ }^{218}$ and along with limited public ownership and participation, these "meant a process focused more on elimination of a foe than any future transformation of the state". ${ }^{219}$ Finally, those who were convicted in abstentia did not serve their sentence which renders the efforts ineffective.

\footnotetext{
${ }^{207}$ Leyh, (2006), ibid.

${ }^{208}$ Firew, (2013); Vaughan, (2009), ibid.

${ }^{209}$ Vaughan, (2009), pp. 62-63, ibid.

${ }^{210}$ Vaughan, (2009), ibid.

211 Independent, (1996); Vaughan, (2009), ibid.

${ }^{212}$ HRW, (1994), ibid, p. 18

${ }^{213}$ Elgesem, F. \& Girmachew Alemu Aneme (2009). The Rights of the Accused: A Human Rights Appraisal. In K. Trovoll, Charels S. \& Girmachew Alemu Aneme (eds), The Ethiopian Red Terror Trials: Transitional Justice Challenged (pp. 17-32). Suffolk: James Currey.

214 See Vaughan, (2009); HRW, (1994), ibid.

${ }^{215}$ Firew K. Tiba (2013), p. 307.

${ }^{216}$ Dadimos Haile. (2000). Accountability for Crimes of the Past and the Challenges of the Criminal Prosecution: The Case of Ethiopia. Leuven: Leuven University Press.

${ }^{217}$ Human Rights Watch (1997), pp. 29-32.

${ }^{218}$ Human Rights Watch, (1997), ibid.

${ }^{219}$ Balint, (2012), Genocide, State Crime and the Law, ibid, p. 91.
} 
Tribunals for the trial of perpetrators of international crimes consisted of both international and national ones. As Leyh ${ }^{220}$ notes, despite the advantages of international tribunals in trying perpetrators and setting precedent of accountability for violations and abuses, it also has limitations. According to Brianne Leyh, the advantages of domestic prosecution of international crimes are numerous.

First, there are many practical benefits. Most domestic prosecutions can claim the benefit of proximity to the evidence or proximity to the witnesses....to prove the guilt of the accused...or secure a conviction. Local engagement with the court often provides legitimacy to the process. ${ }^{221}$

However, limitations to the processes of the domestic prosecutions are also numerous. The most striking challenge and limitations to the domestic prosecutions of international crime, however, is that "when political or ethnic tensions persist, purely domestic prosecutions may not be viewed as legitimate. There is a danger that segment of the population will view the trials as show trials or as being biased towards one side". ${ }^{222}$

\section{Conclusion and Recommendations}

After the demise of the Africa's most brutal dictatorship of Derg, there was hope created by this opportunity that a new chapter of transformation of political culture would take place in Ethiopia. ${ }^{223}$ Given its adverse political and economic situation, adequate consideration should have been given to important aspects of then available measures such as national reconciliation, wider truth inquiry, and amnesty. But the government gave much emphasis for criminal trials. Nevertheless, this paper acknowledges that the Red Terror trials attempted to avoid impunity, restrained summary executions and channeled the cases to be settled at least through judicial mechanisms. Efforts to find truth through trials and producing memorials helped to disclose the horrendous violence of Red Terror days.

However, the paper mainly argued that major limitations of the Ethiopia's measure lies in its narrow approach and rigidity in dealing with the past wrongs. Imposition of victor's interpretation of justice, and strict adherence to criminal trials alone in divided, impoverished and war-torn country, which 'alienated the Ethiopians from reconciling with their past' renders it that the objective to heal wounds is not fully utilized. As one recent work suggested, "moments of crisis are crucial to enabling opportunities for the advance or retreat of inclusion agendas. ... and respond to their opportunities is, therefore, important". ${ }^{224}$ The Ethiopian political tradition founded on domination and subordination ${ }^{225}$ also crippled honest and inclusive negotiations during crisis. Moreover, judicial and institutional weaknesses severely hampered the

\footnotetext{
${ }^{220}$ Leyh, B. M., (2016). National and Hybrid Tribunals: Benefits and Challenges. In P. Malcontent (ed.), Facing the Past: Amending Historical Injustices through Instruments of Transitional Justice （pp, 115-137). Antwerp: Antwerp: Intersentia.

${ }^{221}$ Leyh (2016), National and Hybrid Tribunals, ibid, (p. 117).

${ }^{222}$ Leyh, (2016), ibid, p. 118.

223 Merera Gudina. (1994). The Ethiopian Transition from Military Autocracy to Popular Democracy?: Some Major Issues for Consideration in Crossing the Croassroads. Ufahamu: Journal of African Studies, 22(1-2), pp. 64-88.

${ }^{224}$ British Academy. (2017). Navigating Inclusion in Peace Settlements: Human Rights and the Creation of the Common Good, UK: London, p.53.

${ }^{225}$ Vaugan, S and Tronvoll, K (2003), The Culture of Power in Contemporary Ethiopian Political Life, Sida Studies.
} 
Legide: The Facets of Transitional Justice and Red Terror Trials in post-1991 Ethiopia

due process of law during the trial, while ongoing human rights violations by new regime questioned the legitimacy of the measures. These limitations coupled with what Merera terms 'contradictory interpretations Ethiopian historiography ${ }^{226}$ constrained the capacity of the Red Terror trials that it falls short of being translated into lasting legacy of meaningful socio-political transformation. Therefore, this paper recommends that the current government should consider that the mandate of National Reconciliation Commission established recently to deal with current political violence ${ }^{227}$ should also be widened to integrate tragedy of Red Terror to corroborating SPO's findings, addressing its deficiencies and foster common understanding of that episode. The government should also make public important documents, evidences, and should also establish national memorials to honor victims.

\section{Selected References}

African Commission on Human and Peoples' Rights (2019), Study on Transitional Justice and Human and Peoples' Right in Africa, ACHPR, Banjul.

Aiken, Nevin T. (2013), Identity, Reconciliation and Transitional Justice: Overcoming Intracticability in Divided Societies, Oxon: Routledge.

Amnesty International. (16 Feb. 1993). Amnesty International's Concerns Regarding the Continued Detention in Ethiopia of Officials of the Former Government. Toronto: Amnesty International.

Andrieu, K. (2014). Political Liberalism after Mass Violence; John Rawls and a 'Theory' of Transitional Justice, In Zustel et al. (eds), Transitional Justice Theories, (pp. 85-104), Routledge.

Aregawi Berhe. (2008). A Political History of the Tigray Peoples' Liberation Front: Revolt, Ideology and Mobilization in Ethiopia. Tsehai Publishers.

Babile Tola. (1989). To kill a generation. Washington DC: Free Ethiopia Press.

Bahru Zewde. (1991). The History of Modern Ethiopia ( $1^{\text {st }}$ ed). London: James Currey.

. (2009). The History of Red Terror: Contexts \& Consequences. In K. Trovoll, C. Schaefer and Girmachew Alemu Aneme (eds.). The Ethiopian Red Terror Trials: Transitional Justice Challenged (pp. 17-32). Suffolk: James Currey.

. (2014). The Quest for Socialist Utopia: The Ethiopian Student Movement c. 1960-74. London: James Currey.

Balint, J. (2012). Genocide, State Crime and the Law: In the Name of the State. Oxon: Routledge.

Balsvik, R. (1985). Haile Sellassie's Students: The Intellectual and Social Background to Ethiopian Revolution, 1952-1977. East Lansing: Michigan State University Press.

Bouwknegt, T. B. (2018). Eshetu Alemu: 'The Black Sheep of the Dergue': Ethiopian War Crimes and Universal Jurisdiction in the Netherlands. International Journal of Transitional Justice, 12(3), 549- DOI: 10.1093/ijtj/ijy024

Bouwknegt, T.B. \& Nistor, A. (2019). Studying 'Perpetrators' Through the Lens of the Criminal Trial. In A. Smeulers, M. Weerdesteijn, \& B. Holá, (eds.), Perpetrators of $\quad$ International Crimes: Theories, Methods and Evidence. (pp. 89-116). Oxford: Oxford University Press.

\footnotetext{
${ }^{226}$ Merera Gudina (2006), Contradictory Interpretation of Ethiopian Historiography: Towards a New Consensus, In David Turton (ed.), Ethnic Fderealism: The Ethiopian Experience in Comparative Perspective, London: James Currey (pp. 119-130).

${ }^{227}$ The Ethiopian Herald, (December 26, 2018).
} 
Brankovic, J. and Hugo van der Merwe, (eds.) (2019), Advocating Transitional Justice: The Role of Civil Society, Springer.

British Academy. (2017). Navigating Inclusion in Peace Settlements: Human Rights and the Creation of the Common Good, UK: London

Buckley-Zistel, S., Beck. T. K., Braun, C. \& Mieth, F. (2014). Transitional Justice Theories: An Introduction. In S. Buckley-Zistel, T. Koloma Beck, C. Braun \& F. Mieth (eds.), Transitional Justice Theories (pp. 1-16). Oxon and New York: Routledge.

Corradetti, C, Eisikovits, N. and Rotondi, JV, (eds.) (2015), Theorizing Transitional Justice, Surrey: Ashgate.

Clapham, C. (1988). Transformation and Continuity in a Revolutionary Ethiopia, Cambridge: Cambridge University Press.

Conley, B. (2019). Memory from the Margins: Ethiopia's Red Terror Martyrs Museum, Palgrave MacMillan.

- (April 8, 2019). The Red Terror Martyrs Memorial Museum on Ethiopia's memorial landscape. Retrieved from: https://sites.tufts.edu/reinventingpeace/2019/04/08/the-red- terrormartyrs-memorial-museum-on-ethiopias-memorial-landscape/.

Dadimos Haile. (2000). Accountability for Crimes of the Past and the Challenges of the Criminal Prosecution: The Case of Ethiopia. Leuven: Leuven University Press.

de Greiff, P. (2006). Introduction: Repairing the Past: Compensations for the Victims of Human Rights Violations. In Pablo de Greiff (ed.). Handbook of Reparations (pp. 1-20), Oxford: Oxford University Press.

de Waal, A. (2019) [Review published for Blurb to] Conley, B., (2019). Memory from the Margins: Ethiopia's Red Terror Martyrs Museum. Palgrave: MacMillan.

du Bois-Pedain, A. (2007). Transitional Amnesty in South Africa. Cambridge: Cambridge University Press.

Elgesem, F. \& Girmachew Alemu Aneme (2009). The Rights of the Accused: A Human Rights Appraisal. In K. Trovoll, Charels S. \& Girmachew Alemu Aneme (eds), The Ethiopian Red

Terror Trials: Transitional Justice Challenged (pp. 17-32). Suffolk: James Currey.

Ethiopia (1991). Proclamation No. 3/91, Peaceful Demonstrations and Public Meeting Procedure Proclamation, Addis Ababa.

Ethiopia (1993). Proclamation No. 23/92, A Proclamation to Provide for the Independence of the Judicial Administration. Transitional Government of Ethiopia: Addis Ababa.

Ethiopia (1994). Special Public Prosecutor's Office Establishment Proclamation, Proclamation No. 22/1991. Transitional Government of Ethiopia: Addis Ababa.

Ethiopia \& Office of the Special Prosecutor. (28 Jan. 1994). Ethiopia: Report of the Office of the Special Prosecutor, Letter from the Permanent Representative of the Transitional Government of Ethiopia to the United Nations Office at Geneva, Addressed to the Assistant SecretaryGeneral for Human Rights. Geneva: UN, 1994. Retrieved from: https://www.usip.org/publications/1993/01/special-prosecutors-office-ethiopia

Ethiopia \& SPO Report, (Feb. 1994), Ethiopia: Report of the Office of the Special Prosecutor, The Special Prosecution Process of War Criminals and Human Rights Violators in Ethiopia. In N. J. Kritz (ed.). Transitional Justice: How Emerging Democracies Reckon With Former Regimes (pp. 559-575). Washington DC: The United States Institute of Peace. 
Federal Democratic Republic of Ethiopia (FDRE) (1995). FDRE Constitution of 1995, Proc. No. 1/1995, $1^{\text {st }}$ Year, No. 1, $21^{\text {st }}$ August 1995, Addis Ababa.

Frew Tiba (2011). The Trial of Mengistu and Other Derg Members for Genocide, Torture and Summary Executions in Ethiopia. In C. Murungu \& J. Biegon (eds.), Prosecuting International Crimes in Africa (pp. 163-183). Pretoria: Pretorial University Law Press.

(2013). Mass Trials and Modes of Criminal Responsibility for International Crimes: The Case of Ethiopia. In K. Heller \& G. Simpson (eds.). The Hidden Histories of War Crimes Trials (pp. 306324). Oxford: Oxford University Press.

Fletcher, L. \& Weinstein, H. (2002). Violence and Social Repair: Rethinking the Contribution of Justice and Reconciliation. Human Rights Quarterly, 24 (3), 594-596.

Gallen, J. (2017). The International Criminal Court: In the Interests of Transitional Justice? In C. Cheryl, L. Moffet \& D. Jacobs (eds.), Research Handbook on Transitional Justice (pp. 305-327). Cheltenham: Edward Elgar Publishing.

Girmachew Alemu Aneme (2006). Apology and Trials: The Case of the Red Terror Trials in Ethiopia. Journal of African Human Rights Law (6), 64-84.

. (2009a). Beyond the Red terror Trials: Analysing Guarantees of Non-Repetition, in In K. Tronvoll, C. Schaefer \& Girmachew Alemu Aneme (eds), The Ethiopian Red Terror Trials: Transitional Justice Challenged (pp. 116-135). Suffolk: James Currey. . (2009b). The Anatomy of Specials Prosecutor vs. Colonel Mengistu Hailemariam et. al (19942008). The International Journal of Ethiopian Studies (4)1 \&2), 1-53.

Hamber, B. (2009), Transforming societies after Political Violence: Truth, Reconciliation, and Mental Health. London and New York: Springer.

Human Rights Watch (1994). Ethiopia: Reckoning Under the Law, Vol. 6, No. 11. Retrieved from: https://www.hrw.org/sites/default/files/reports/ethiopia94d.pdf

Human Rights Watch. (1 Dec.1997). Ethiopia- The Curtailment of Rights, Retrieved from: https://www.refworld.org/docid/3ae6a8554.html [accessed 21 May 2019].

Huyse, L. (2008). Introduction: Tradition-based Approaches in Peacemaking, Transitional Justice and Reconciliation Policies. In L. Huyse (ed.). Traditional Justice and Reconciliation after Violent Conflcit: Learning From African Experiences. IDEA, Stockholm. . (2009). All Thingd Pass, Except the Past. New Goff, Mariakerke: AWEPA. .(2013). Transitional Justice After War and Dictatorship: Learning from European Experiences (1945-2010), Centre for Historical Research and Documentation on War and Contemporary Society CEGES-SOMA. Retreived from: http://www.cegesoma.be/docs/media/Recherche/TransJustFinalReport.pdf

Independent. (1 April 1996). Masters of Ethiopia's Red Terror Face Trial for Genocide. Retrieved from :https://www.independent.co.uk/news/world/masters-of-ethiopias-red- terror- face- trialfor-genocide-1302752.html

(13 Dec, 2006). Mengistu found guilty of Ethiopian Genocide, retrieved from https://www.independent.co.uk/news/world/africa/mengistu-found-guilty-of- ethiopiangenocide-428233.html

Jarstad, A.K., \& Sisk, T.D., (eds.). (2008). From War to Democracy: Dilemmas of Peacebuilding. Cambridge: Cambridge University Press.

Kiflu Tadesse, (1993). The Generation: The History of Ethiopian Peoples' Revolutionary Party, Part I. 
Kim, NK \& Hong, MH, (2016). Politics of Pursuing Justice in the Aftermath of Civil Conflict. Faculty Publications: Political Science. Paper 77.

(available: http://digitalcommons.unl.edu/poliscifacpub/77).

Lawther, Cheryl, Moffet, L. \& Jacobs, D., (eds.), Research Handbook on Transitional Justice, Cheltenham: Edward Elgar Publishing.

Leyh, B. M., (2016). National and Hybrid Tribunals: Benefits and Challenges. In P. Malcontent (ed.), Facing the Past: Amending Historical Injustices through Instruments of Transitional Justice (pp, 115-137). Antwerp: Intersentia.

Maogoto, J. N. (2013). Reading the Shadows of History: The Turkish and Ethiopian 'Internationalized' Domestic Crime Trials. In K. Heller and G. Simpson (eds.), The Hidden Histories of War Crimes Trials (pp. 289-305). Oxford: Oxford University Press.

Markakis, J. (2011). Ethiopia: The Last Two Frontiers. Suffolk ans New York: James Currey.

Marshet Ayele. (2018). Prosecution of Politicide in Ethiopia: The Red Terror Trials. The Hague: Asser Press.

McAuliffe, P. (2017). Transformative Transitional Justice and the Malleability of Post-conflict States. Cheltenham: Edward Elgar.

McEvoy, K. (2007). Beyond Legalism: Towards a Thicker Understanding of Transitional Justice, Journal of Law and Society, (34) 4, 411-40.

(2008), Letting Go of Legalism: Developing a 'Thicker' Version of Transitional Justice, In

McEvoy and McGregor (eds.), Transitional Justice from Below: Grassroots Activism and the Struggle for Change, London: Hart Publishing

Merera Gudina. (1994). The Ethiopian Transition from Military Autocracy to Popular Democracy? Some Major Issues for Consideration in Crossing the Crossroads. Ufahamu: Journal of African Studies, 22(1-2), pp. 64-88.

. (2003). Competing Ethnic Nationalism and the Quest for Democracy, 1960-2000, Maastricht: Shaker Publishing.

(2006). Contradictory Interpretations of the Ethiopian Historiography: The Need for a New Consensus. In D. Turton, D. (ed.). Ethnic Federalism: The Ethiopian Experience in a Comparative Perspective (pp. 119-130). Oxford: James Currey.

Mihr, A. (2017), Regime Consolidation through Transitional Justice in Europe: The Case of Germany, Spain, Turkey, International Journal of Transitional Justice Vol. 11, Issue 1, pp. 113-131.

Moffett, L. (2017). Transitional Justice and Reparations: Remedying the Past? In L. Cheryl, L. Moffet \& D. Jacobs. (eds.). Research Handbook on Transitional Justice (pp. 377-400). Cheltenham: Edward Elgar Publishing.

Murphy, C. (2015), Transitional Justice, Retributive Justice and Accountability for Wrongdoing, In Corradetti, C, Eisikovits, N. and Rotondi, JV, (eds.) (2015), Theorizing Transitional Justice, Ashgate Publishing.

Newman, M. (2019), Transitional Justice: Contending with the Past, Cambridge: Polity Press.

New York Times. (June 04, 2006), The Long Interrogation. Retrieved from: https://www.nytimes.com/2006/06/04/magazine/04torturer.html?ei=5088\&en=f88ce4 083 b9ca $61 \mathrm{~d} \&$ ex $=1307073600 \&$ partner=rssnyt\&emc=rss\&pagewanted=print.

Olsen, T. D, Paine, L. A \& Andrews G. Reiter, A. G (2010), Transitional Justice in Balance: Comparing Processes, Weighing Efficacy, Washington, D, C: United States Institute of Peace 
Onegi, L. (2012). Introduction in Moses Chrispus Okello el al (eds), Where the Law Meets Reality: Forging African Transitional Justice, Cape Town: Pambazuka Press.

Penal Code of The Empire of Ethiopia (1957), Proclamation No. 158 of 1957, Negarit Gazeta, Extraordinary Issue No. 1 of 1957, 23 July 1957.

Prevent Genocide International. Retrieved: http://preventgenocide.org/law/domestic/ethiopia.htm

Prunier, G. (2015). The Ethiopian Revolution and the Derg Regime. In G. Prunier \& E. Ficquet (eds.). Understanding Contemporary Ethiopia: Monarch, Revolution and the Legacy of Meles Zenawi, London: Hurst, pp. 209-232.

Quinn, Joanna R. (2017), The Development of Transitional Justice, In Lawther, Cheryl, Moffet, L. \& Jacobs, D., (eds.), Research Handbook on Transitional Justice, Cheltenham: Edward Elgar Publishing, pp. 11-33.

Reuters, (Jan. 20, 2007), Ethiopia's Mengistu found Guilty of Genocide. Retrieved from: https://www.reuters.com/article/us-ethiopia-mengistu-genocide/ethiopias-mengistu- foundguilty-of-genocide-idUSL1286585920061212

Rikhof, J. (2018). Case Comment: Dutch Court Convicts Ethiopian War Criminal to Life Imprisonment, PKI Global Just J. 3. Retrived from: http://www.kirschinstitute.ca/case- comment-dutch-courtconvicts-ethiopian-war-criminal-life-imprisonment/

Rohne, H. C., Arsovska, J., \& Aertsen, I. (2008). Challenging Restorative Justice-State-based Conflict, Mass Victimsation and the Changing Nature of Warfare. In I. Aertsen, J. Arsovska, H.C. Rohne, M. Valinas \& K. Vanspauwen (eds.). Restoring Justice After LargeScale Violent Conflicts: Kosovo, DR Congo and the Israeli-Palestinian Case (pp. 3-45). Devon: William Publishing.

Roht-Arriaza, N. (2006). The New Landscape of Transitional Justice. In N. Roht-Arriaza and J. Mariezcurrena (eds.), Transitional Justice in the Twenty-First Century: Beyond Truth Versus Justice (pp. 1-16). Cambridge: Cambridge University Press.

Ryle, J. (1996). The Trial of the Derg in Ethiopia: A Reporter's Story, Einstein Forum, Potsdam, Retrieved from: https://johnryle.com/?article=the-trial-of-the-derg-in- ethiopia

Schabas, William A. (2002), Unimaginable Atrocities: Justice, Politics and Rights at the War Crimes Tribunal, Oxford: Oxford University Press

Skaar, E. (2013), Transitional Justice Methods, Processes and Practices, In Nadya Nedelsky and Lavinia Stan (eds.), Encyclopedia of Transitional Justice, New York: Cambridge University Press, Vol. 1.

Sriram, C. Lekha, (2009). Justice as Peace? Liberal Peacebuilding and Strategies of Transitional Justice. In Roger Mac Ginty and Oliver Richmond (eds.), The Liberal Peace and the Post-War Reconstruction: Myth or Reality? Oxon: Routledge.

Susanne Buckley-Zistel, Teresa Koloma Beck, Christian Braun and Friedrike Mieth (2014), Transitional Justice Theories: An Introduction In Susanne Buckley-Zistel, Teresa Koloma Beck, Christian Braun and Friedrike Mieth (eds.), Transitional Justice Theories, Oxon and New York: Routledge

Tadesse Simie Metekia (2018). Violence against and Using the Dead: Ethiopia's Derg Cases, Human Remains and Violence, (4) 1, 76-92.

(2019). Punishing Core Crimes in Ethiopia: Analysis of the Domestic Practice in Light of and in Comparison with Sentencing Practices at the UNICTS and the ICC, International Criminal Law Review 19, 160-190. Doi 10.1163/15718123-01901007.

Teitel, Ruti G. (2000), Transitional Justice, Oxford: Oxford University Press. 
(2014), Globalizing Transitional Justice: Contemporary Essays. Oxford: Oxford University

Press.

TGE. (1992). Proclamation No. 22/1992, A Proclamation for the Establishment of the Special Prosecuror's Office, Negarit Gazeta No. 18, 1993. Addis Ababa.

The Economist (2007). Ethiopia: An Archive of Murder Past. Retrieved from, https://www.economist.com/middle-east-and-africa/2007/09/27/an-archive-of- murderspast

The Ethiopian Herald, (December 26/2018). House Approves Proclamation to Establish National Reconciliation Commission, Retrieved from: https://press.et/english/?p=919\#

The Washington Post. (13 December 2006). Exiled Ethiopian Dictator Found Guilty of Genocide. retrieved from http://www.washingtonpost.com/wpdyn/content/article/2006/12/12/AR200612120044 7.html

Tronvoll, K. \& Vaughan, S. (2003). The Culture of Power in Contemporary Ethiopian Political Life, Sida Studies, No. 10, Swedish International Development Copperation Agency, Sida.

Tronvoll, K. (2009). A Quest for Justice or the Construction of Political Legitimacy?: The Political Anatomy of the Red Terror Trials. In K. Trovoll, C. Schaefer \& Girmachew Alemu Aneme (eds), The Ethiopian Red Terror Trials: Transitional Justice Challenged (pp. 84-97). Suffolk: James Currey.

Trovoll, K., Schaefer, C. \& Girmachew Alemu Aneme (2009). The 'Red Terror' Trials: The Context of Transitional Justice in Ethiopia. In K. Trovoll, C. Schaefer, \& Girmachew Alemu Aneme (eds). The Ethiopian Red Terror Trials: Transitional Justice Challenged. (pp. 1-16). Suffolk: James Currey.

(2013). Ethiopia, In Encyclopedia of Transitional Justice, Vol. 2, (pp.167-173). Cambridge: Cambridge University Press.

Turner, C. (2017), Transitional Justice and Critique, In Cheryl Lawther, Luke Moffet and Dov Jacobs (eds), A Research Handbook of Transitional Justice, Edward Elgar, pp. 52-73.

UN (2004), Report of the Secretary-General on the Rule of Law and Transitional Justice in Conflict and Post-Conflict Societies.

United States Institute of Peace (1993). Ethiopia: Special Prosecutor's Office, retrieved: https://www.usip.org/publications/1993/01/special-prosecutors-office-ethiopia

United States Bureau of Citizenship and Immigration Services (1 December 1994). Ethiopia: $\quad$ Update on Political Conditions,

Retrieved from: https://www.refworld.org/docid/3ae6a609c.html [accessed 24 May 2019]

UN Security Council, "The Rule of Law and Transitional Justice in Conflict and Post-conflict Societies: Report of the Secretary-General" (23 August 2004) UN Doc. S/2004/616, 4.

Vaughan, S. (1994). The Addis Ababa Transitional Conference of July 1991: Its Origins, History, and Significance. Center of African Studies, Edinburgh University, Occasional Papers, No. 51. Edinburgh, UK.

(2009). The Role of the Special Prosecutor's Office. In K. Trovoll, C. Schaefer \& Girmachew Alemu Aneme (eds). The Ethiopian Red Terror Trials: Transitional Justice Challenged, (pp. 5167). Suffolk: James Currey.

Wiebel, J. (2015). Let the Red Terror intensify: political violence, governance and society in urban Ethiopia, 1976-78. International journal of African historical studies, 48 (1), 13- 30.

(2017). The Ethiopian Red Terror. In T. Spear (ed.), Oxford Research Encyclopedia: African History, (pp. NA). Oxford: Oxford University Press. 
White, Cheryl S. (2017), Bridging Divides in Transitional Justice: The Extraordinary Chambers in the Courts of Cambodia, Antwerp, Cambridge: Intersentia.

Williams, T. and Buckley-Zistel (2018), Perpetrators and Perpetrators of Mass Violence: Actions, Motivations and Dynamics ( $1^{\text {st }}$ ed.), Oxon: Routledge. 